\section{Soil-surface nutrient distributions in grazed pastures of North Carolina}

\author{
A.J. Franzluebbers, M.H. Poore, S.R. Freeman, and J.R. Rogers
}

\begin{abstract}
Soil nutrient distribution in perennial pastures is likely affected by livestock activities, but detailed spatial patterns on a diversity of farms have not been widely investigated. Livestock management variables, such as placement of drinking water sources, fencing, and winter hay-feeding stations, as well as pasture utilization through seasonal stocking, could affect nutrient distribution despite attempts at uniform application of fertilizers. We sampled perennial pasture portions of three research station farms in North Carolina on a $40 \mathrm{~m}$ grid in 2016. Twenty-two soil variables were measured, including routine soil testing of $\mathrm{pH}$, cation exchange capacity, and extractable phosphorus $(\mathrm{P})$, potassium $(\mathrm{K})$, calcium $(\mathrm{Ca})$, and magnesium $(\mathrm{Mg})$, as well as nonroutine testing of sand concentration, total and particulate organic carbon $(\mathrm{C})$ and nitrogen $(\mathrm{N})$, and soil-test biological activity. Large statistical variations in nearly all variables occurred within a location. Severely deficient and heavily excessive levels of soil-test $\mathrm{P}$ and $\mathrm{K}$ were observed on the same farm and sometimes on the same paddock. Soil-test biological activity and total soil $\mathrm{N}$ also varied spatially within locations. High nutrient concentrations and soil-test biological activity were congregated in zones of several pastures, which could be related to historical winter hay-feeding and permanent drinking water locations. At the Piedmont location with recent winter hay feeding, both organic and inorganic indicators generally corresponded to the same enrichment zones. At the Coastal Plain location with abandonment of some historical feeding locations, soil-test $\mathrm{P}$ remained high near feeding stations, but soil-test $\mathrm{K}$ and total soil $\mathrm{N}$ became more uniformly distributed due to leaching and/or decomposition dynamics over time. We suggest that both organic and inorganic soil testing indicators should be measured to make nutrient recommendations for better resource utilization. Livestock managers are encouraged to sample pastures in expected zones of nutrient differentiation so that nutrients can be used efficiently and environmental threats can be mitigated.
\end{abstract}

Key words: carbon-nitrogen-phosphorus—routine soil testing-soil-test biological activity - spatial distribution

\section{Grazed pastures are common throughout the southeastern region of the United States (USDA NASS 2012). In the 11-state} region (Alabama, Arkansas, Delaware, Florida, Georgia, Louisiana, Maryland, Mississippi, North Carolina, South Carolina, and Virginia), pastureland occupies 8.9 Mha. Nationally, grazing lands occupy 184.6 Mha. Grassland in the region occurs on 218,012 farms with an average land area of 41 ha per farm. In North Carolina, land devoted to forages occurs on 30,649 farms and covers 19 ha per farm.

Pastures are an important source of forage for ruminant livestock, allowing animals to harvest their own feedstock ad libitum. the pasture. However, livestock have behav ioral patterns that create uneven distribution between grazing intake and elimination (Richards and Wolton 1976). For example, livestock may spend a disproportionate amount of time defecating and urinating near shade and water sources after lounging and rumination (Augustine et al. 2013). This may result in elevated soil organic matter and nutrient concentrations near shade and water sources (West et al. 1989; Schomberg et al. 2000; Sigua and Coleman
2006; Franzluebbers and Stuedemann 2010), as well as denuded areas from frequent trampling that can expose nutrients to runoff loss.

Livestock may also preferentially consume desirable forage species that dominate in favorable positions of the landscapes, e.g., lowland areas with enriched soil and available moisture for forage growth. In contrast, livestock may denude portions of the landscape due to frequent trampling that limits forage regrowth. Therefore, landscape variability regarding pasture nutrient distribution can be a cause for concern of nutrient runoff (DeLaune et al. 2004; Butler et al. 2007; Sanderson et al. 2010), lead to questionable forage growth response to applied nutrients (Franzluebbers et al. 2018), and create constraints and opportunities to enhance resource efficiency of farming operations.

Although zones of concentrated livestock activity that destroy surface vegetation are likely prone to elevated nutrient accumulation and water runoff, surrounding vegetation can limit nutrient movement (Sanderson et al. 2010), and other landscape features and management approaches may mitigate negative environmental consequences. Limited research exists to assess nutrient distribution in grazed pastures, as well as to associate these variations in nutrient distribution to landscape features and management. Our goal was to address these data limitations by studying a variety of chemical, physical, and biological soil properties that indicate nutrient distribution and potential microbial activity patterns on three research station farms in North Carolina with routine management practices typical of beef farm operations in the region.

We chose the flush of carbon dioxide $\left(\mathrm{CO}_{2}\right)$ following rewetting of dried soil (i.e., soil-test biological activity) as a general indicator of soil biological activity (Franzluebbers 2016), since it has been recently shown in strong association with soil nitrogen $(\mathrm{N})$ availability in corn (Zea mays L.) (Franzluebbers 2018)
Alan J. Franzluebbers is a research ecologist with the USDA Agricultural Research Service (ARS) in Raleigh, North Carolina. Matt H. Poore is beef extension specialist with North Carolina State University in Raleigh, North Carolina. Sharon $\mathbf{R}$. Freeman is research associate with North Carolina State University in Raleigh, North Carolina. Johnny R. Rogers is extension associate with North Carolina State University in Raleigh, North Carolina. 
and tall fescue (Lolium arundinaceum [Schreb.] Darbysh. $=$ Schedonorus arundinaceus [Schreb.] Dumort.) pastures (Franzluebbers et al. 2018). High soil-test biological activity indicates plentiful carbon (C) resources necessary for rapid organic matter decomposition and nutrient mineralization. We supplemented assessment of soil-test biological activity with additional indicators of particulate organic C and $\mathrm{N}$ concentrations, as these intermediately decomposed $\mathrm{C}$ and $\mathrm{N}$ fractions reflect contributions from both root accumulation and residual forage mass inputs over the long term (Cambardella and Elliott 1992; Franzluebbers and Studemann 2002).

\section{Materials and Methods}

Site Characteristics and Management. Research stations in the Coastal Plain region (Cherry Research Farm, 909 ha), Piedmont region (Beef Cattle Center, $>1,600 \mathrm{ha}$ ), and Blue Ridge region (Mountain Research Station, 166 ha) in North Carolina were selected for this evaluation (table 1). Livestock stakeholders are important near all three locations. Research stations were jointly administered by North Carolina Department of Agriculture and Consumer Services and North Carolina State University.

The Coastal Plain sampling location consisted of several adjacent grazed pastures that had been under perennial and annual forages for at least 30 years. Naturalized trees (primarily sweet gum [Liquidambar styraciflua L.] and bald cypress [Taxodium distichum (L.) Rich.]) were part of the landscape along drainage areas, permanent (three-wire galvanized tensile) and temporary (single polywire) electric fences were used to manage cattle, and an animal handling facility was located central within our sampling domain (but not sampled). A total of 27 ha was sampled in seven pastures on a relatively flat landscape adjacent to the Neuse River with major landscape features of a drainage cut and heavy use areas related to handling facility, drinking water sources, gates, and trees as shade sources (figure 1). Pastures 1 to 4 had long-standing, naturalized warm-season forage mixtures, including common bermudagrass (Cynodon dactylon L.), bahiagrass (Paspalum notatum Flueggé), dallisgrass (Paspalum dilatatum Poir.), and hairy crabgrass (Digitaria sanguinalis [L.] Scop.). These pastures were typically overseeded in the fall with cool-season annual grasses (e.g., annual ryegrass [Lolium multiflorum L.]) or wheat (Triticum aestivum L.). Pasture 5 was seeded to 'Ranchero Frio' and 'Cheyenne II' hybrid bermudagrass in 2008 and initially grazed, but in recent years cut in the summer for hay with no overseeding. Crabgrass and dallisgrass were occasionally present. Pastures 6 and 7 were historically in mixed warm-season perennial pastures and converted a few years prior to sampling to summer and winter annuals, including pearl millet (Pennisetum glaucum [L.] R. Br.) and annual ryegrass for grazing. The eastern half of Pasture 3 had been used for winter hay feeding and calving for many years due to proximity to a central handling facility. Winter hay-feeding stations for spring calving were also placed in Pasture 4 near the handling facility, where soil was sandier and elevation was higher than other parts of the pasture. Pasture 5 had historically been a winter hay-feeding pasture prior to management for hay harvest. Pastures 1 to 4 were typically fertilized one to two times per year with urea-ammonium nitrate (UAN) at 34 to $56 \mathrm{~kg} \mathrm{~N} \mathrm{ha}^{-1}$ and every other year with potash at $67 \mathrm{~kg} \mathrm{~K} \mathrm{O} \mathrm{ha}^{-1}$.

Table 1

Location, climatic, and soil characteristics of the three sites in North Carolina.

\begin{tabular}{|c|c|c|c|c|c|}
\hline Sites & Location & $\begin{array}{l}\text { Mean annual } \\
\text { temperature } \\
\left({ }^{\circ} \mathrm{C}\right)\end{array}$ & $\begin{array}{l}\text { Mean annual } \\
\text { precipitation } \\
(\mathrm{mm})\end{array}$ & $\begin{array}{l}\text { Elevation } \\
\text { (masl) }\end{array}$ & Soils \\
\hline Coastal Plain & $35^{\circ} 22^{\prime} \mathrm{N}, 78^{\circ} 2^{\prime} \mathrm{W}$ & 15.3 & 1,192 & 25 & $\begin{array}{l}\text { Lakeland sand (thermic, coated Typic Quartz } \\
\text { ipsamments), Troup sand (loamy, siliceous, ther- } \\
\text { mic Grossarenic Kandiudults), Kalmia loamy sand } \\
\text { (fine-loamy over sandy or sandy-skeletal, siliceous, } \\
\text { semiactive, thermic Typic Hapludults), } \\
\text { Kenanville loamy sand (loamy, siliceous, subac- } \\
\text { tive, thermic Arenic Hapludults), Johns sandy } \\
\text { loam (fine-loamy over sandy or sandy-skeletal, } \\
\text { siliceous, semiactive, thermic Aquic Hapludults), } \\
\text { and Lumbee sandy loam (fine-loamy over sandy or } \\
\text { sandy-skeletal, siliceous, subactive, thermic Typic } \\
\text { Endoaquults) }\end{array}$ \\
\hline Piedmont & $36^{\circ} 10^{\prime} \mathrm{N}, 78^{\circ} 48^{\prime} \mathrm{W}$ & 14.0 & 1,113 & 146 & $\begin{array}{l}\text { Helena sandy loam (fine, mixed, semiactive, } \\
\text { thermic Aquic Hapludults), Herndon silt loam (fine, } \\
\text { kaolinitic, thermic Typic Kanhapludults), Lignum } \\
\text { silt loam (fine, mixed, semiactive, thermic Aquic } \\
\text { Hapludults), and Wehadkee silt loam (fine-loamy, } \\
\text { mixed, active, nonacid, thermic Fluvaquentic En- } \\
\text { doaquepts) }\end{array}$ \\
\hline Blue Ridge & $35^{\circ} 29^{\prime} \mathrm{N}, 82^{\circ} 58^{\prime} \mathrm{W}$ & 12.1 & 1,199 & 810 & $\begin{array}{l}\text { Evard-Cowee complex (fine-loamy, parasesquic, } \\
\text { mesic Typic Hapludults), Braddock clay loam (fine, } \\
\text { mixed, subactive, mesic Typic Hapludults), and } \\
\text { Hayesville clay loam (fine, kaolinitic, mesic Typic } \\
\text { Kanhapludults) }\end{array}$ \\
\hline
\end{tabular}




\section{Figure 1}

Aerial maps of three sampling locations with grazed pastures in the Coastal Plain, Piedmont, and Blue Ridge regions of North Carolina.
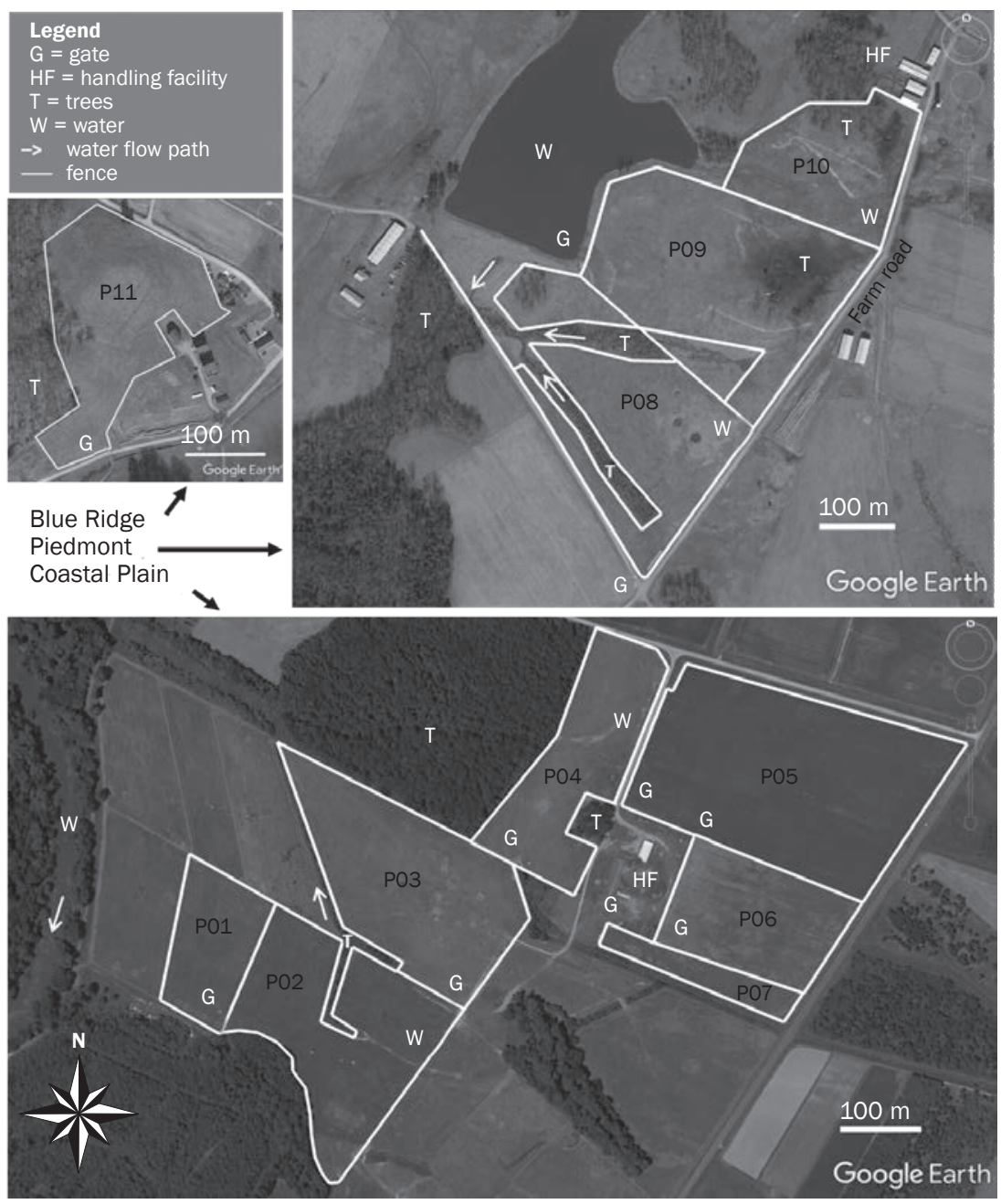

Pasture 5 was typically fertilized during hay production with UAN three times per year at $45 \mathrm{~kg} \mathrm{~N} \mathrm{ha}^{-1}$ per application and one to two times per year with potash at $67 \mathrm{~kg}$ $\mathrm{K}_{2} \mathrm{O} \mathrm{ha}^{-1}$ per application.

The Piedmont location consisted of three pastures along with significant conservation reserve grassland and tree plantings in waterways next to a farmstead impoundment (figure 1). Pastures were under perennial forages for at least 30 years following timber harvest and land clearing. Dominant forage species was tall fescue, but significant contributions also occurred seasonally from bermudagrass, dallisgrass, and crabgrass. Trees were part of a legacy upland site along with rock outcrop, as well as planted bald cypress along a wetland, conservation corridor in 2000. Permanent fences separated pastures, and cattle were fed hay during winter months at upland locations along the road. A total of 19 ha was sampled.

The Blue Ridge location consisted of one continuously grazed pasture that was at least 50 years old and dominated by tall fescue. Other forage species present were red clover (Trifolium pretense L.), bluegrass (Poa pratensis L.), crabgrass, and yellow foxtail (Setaria pumila [Poir.] Roem.). Natural stands of timber lined the upslope portion of the pasture, while farm buildings and roads were downslope of the pasture (figure 1). One permanent fence surrounded the entire pasture and no temporary fencing was typically used. A hay-feeding station was typically located in the northwestern section along the trees and a grain feeding station was located in the southern section near the gate along the fenceline. Grazing occurred whenever forage was available in spring, summer, and fall. A total of 5 ha was sampled.

Soil Sampling and Analyses. Soil was sampled at each location on a $40 \mathrm{~m}$ grid spacing on May 4, 2016, at the Coastal Plain location; April 5, 2016, at the Piedmont location; and June 28, 2016, at the Blue Ridge location. Sampling dates were selected based on suitable weather and availability of research team (we did not expect sampling date to be a major factor affecting results, since relative variations among sampling sites was most important in this investigation). Sampling points were marked with a flag using a Trimble global positioning system (GPS) unit, and soil was collected immediately thereafter from a composite of seven cores surrounding each point. Cores were located at the center, three equidistant positions $1 \mathrm{~m}$ away from the center, and three equidistant positions 2 $\mathrm{m}$ away from the center. Soil was collected in a $4 \mathrm{~L}$ plastic bucket that contained a hole in the bottom to allow a battery-powered drill (32 $\mathrm{mm}$ diameter bit with $30 \mathrm{~cm}$ long extension bar) to penetrate the bucket and draw soil up from depth of 0 to $10 \mathrm{~cm}$ (figure 2). A total of 250 to $400 \mathrm{~g}$ dry soil (middle $50 \%$ of observations) was collected from each site. Soil was transferred into labeled paper bags in the field and dried in an oven at $55^{\circ} \mathrm{C}$ for three or more days until constant weight. Soil was passed through a $2 \mathrm{~mm}$ screen by crushing with a pestle; stones and plant residues were discarded.

\section{Figure 2}

Photo of battery-powered drill inserted into soil with plastic bucket, which is then able to hold soil following penetration of the bit to $10 \mathrm{~cm}$ depth.

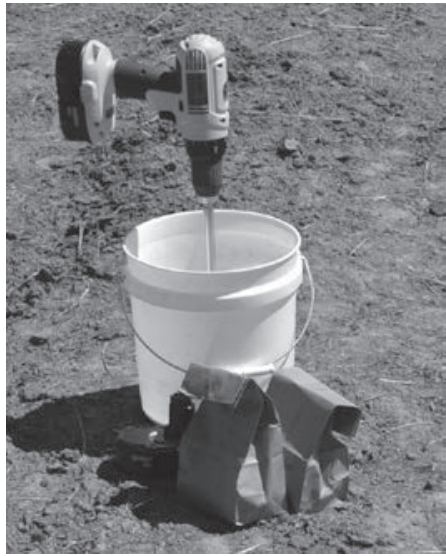


A subsample of each soil was submitted to the North Carolina Department of Agriculture (NCDA) and Consumer Services Soil Testing Laboratory for routine soil-testing estimates of cation exchange capacity (sum of acidity plus base cations), $\mathrm{pH}$ from 1:2 (v:v) of soil:water with glass electrode, base saturation from sum of bases divided by cation exchange capacity, acidity from buffer $\mathrm{pH}$, humic matter from $0.2 \mathrm{M}$ sodium hydroxide $(\mathrm{NaOH})$ extraction, and concentrations of calcium $(\mathrm{Ca})$, copper $(\mathrm{Cu})$, potassium $(\mathrm{K})$, magnesium $(\mathrm{Mg})$, manganese $(\mathrm{Mn})$, phosphorus $(\mathrm{P})$, sulfur (S), and zinc ( $\mathrm{Zn}$ ) with Mehlich-III extraction followed by determination with inductively coupled spectroscopy (NCDA 2017). Bulk density was determined by the NCDA lab from the dry weight of soil contained in a 10 $\mathrm{cm}^{3}$ scoop.

In addition, the following analyses were performed in the Soil Ecology and Management lab at North Carolina State University. Soil-test biological activity was determined from a $50 \mathrm{~g}$ subsample incubated at $25^{\circ} \mathrm{C}$ for three days after rewetting to $50 \%$ water-filled pore space and placed in a $1 \mathrm{~L}$ canning jar in the presence of $10 \mathrm{~mL} 1 \mathrm{M}$ $\mathrm{NaOH}$ (Franzluebbers 2016). Particulate organic $\mathrm{C}$ and $\mathrm{N}$ and sand concentration were determined from this same sample following incubation. The subsample was dried in an oven $\left(55^{\circ} \mathrm{C}\right.$ for three days), transferred to a $250 \mathrm{~mL}$ plastic bottle, shaken with 0.01 $\mathrm{M} \mathrm{Na}_{4} \mathrm{P}_{2} \mathrm{O}_{7}$ for 16 hours, and solution passed over a screen with $0.053 \mathrm{~mm}$ openings to collect the sand fraction $(>0.053 \mathrm{~mm}$ fraction). The sand fraction was dried $\left(55^{\circ} \mathrm{C}\right.$ for 24 hours past visual dryness), weighed, ball milled, and analyzed for $\mathrm{C}$ and $\mathrm{N}$ with dry combustion using a Leco TruMac CN analyzer to determine particulate organic C and N. Another subsample from the original bag of soil was ball milled and analyzed for $\mathrm{C}$ and $\mathrm{N}$ with dry combustion as above to determine total organic $\mathrm{C}$ and $\mathrm{N}$. Total $\mathrm{C}$ was assumed to represent total organic $\mathrm{C}$ since $\mathrm{pH}$ was $\leq 7.0$ for all but 3 of 312 samples. Residual soil ammonium $\left(\mathrm{NH}_{4}^{+}\right)$and nitrate $\left(\mathrm{NO}_{3}^{-}\right)$were determined from the filtered extract of a $10 \mathrm{~g}$ subsample shaken with $20 \mathrm{~mL}$ of $2 \mathrm{M}$ potassium chloride $(\mathrm{KCl})$ for 30 minutes and solution analyzed using salicylate-nitroprusside and hydrazine autoanalyzer techniques (Bundy and Meisinger 1994). Residual inorganic $N$ was the sum of $\mathrm{NH}_{4}{ }^{+}-\mathrm{N}$ and $\mathrm{NO}_{3}^{-}-\mathrm{N}$ concentrations.
Statistical Analyses. Box and whisker plots were constructed to show statistical distribution of data within a location. Boxes represented the central $50 \%$ of data, and whiskers represented the $10 \%$ and $90 \%$ limits. Kolmogorov-Smirnov test was conducted to determine if data sets were skewed from normal distribution $(p \leq 0.05)$. Correlations among response variables were considered significant at $p \leq 0.001-$ a stringent limit due to the large number of observations and variables tested. Spatially explicit data were plotted onto a Google Earth background image using rank categories. Soil nutrients were divided into four categories to aid in visual interpretation of major zones. Soiltest biological activity as an active fraction of $\mathrm{C}$ was divided along limits that were arbitrary, but followed a reasonable gradient described in Franzluebbers (2018): low $\left(<200 \mathrm{mg} \mathrm{CO}_{2}-\mathrm{C} \mathrm{kg}^{-1}\right.$ soil $\left.3 \mathrm{~d}^{-1}\right)$, medium (200 to $300 \mathrm{mg} \mathrm{CO}_{2}-\mathrm{C} \mathrm{kg}^{-1}$ soil $3 \mathrm{~d}^{-1}$ ), high (300 to $400 \mathrm{mg} \mathrm{CO}_{2}-\mathrm{C} \mathrm{kg}^{-1}$ soil $3 \mathrm{~d}^{-1}$ ), and very high (>400 $\mathrm{mg} \mathrm{CO}_{2}-\mathrm{C} \mathrm{kg}^{-1}$ soil $\left.3 \mathrm{~d}^{-1}\right)$. Total soil $\mathrm{N}$ had arbitrary limits according to low (<1 $\mathrm{g} \mathrm{N} \mathrm{kg}^{-1}$ soil), medium (1 to $2 \mathrm{~g}$ $\mathrm{N} \mathrm{kg}^{-1}$ soil), high (2 to $3 \mathrm{~g} \mathrm{~N} \mathrm{~kg}^{-1}$ soil), and very high ( $>3 \mathrm{~g} \mathrm{~N} \mathrm{~kg}^{-1}$ soil). Soil-test $\mathrm{P}$ at the NCDA Soil Testing Lab is categorized as very low (0 to $12 \mathrm{mg} \mathrm{P} \mathrm{dm}^{-3}$ ), low (12 to $30 \mathrm{mg} \mathrm{P} \mathrm{dm}^{-3}$ ), medium (30 to $60 \mathrm{mg} \mathrm{P}$ $\mathrm{dm}^{-3}$ ), high (60 to $120 \mathrm{mg} \mathrm{P} \mathrm{dm}{ }^{-3}$ ), and very high (>120 mg P dm${ }^{-3}$ ) (Hardy et al. 2014). We divided soil-test $\mathrm{P}$ into four categories with our own label of expected nutrient requirement for forages of severely deficient (<30 $\mathrm{mg} \mathrm{P} \mathrm{dm}^{-3}$ soil), moderately deficient (30 to $84 \mathrm{mg} \mathrm{P} \mathrm{dm}^{-3}$ soil), sufficient (84 to $120 \mathrm{mg} \mathrm{P} \mathrm{dm}{ }^{-3}$ soil), and excessive (>120 mg $\mathrm{P} \mathrm{dm}{ }^{-3}$ soil). Soil-test $\mathrm{K}$ at the NCDA Soil Testing Lab is categorized as very low (0 to $20 \mathrm{mg} \mathrm{K} \mathrm{dm}^{-3}$ ), low (20 to $50 \mathrm{mg} \mathrm{K}$ $\mathrm{dm}^{-3}$ ), medium ( 50 to $98 \mathrm{mg} \mathrm{K} \mathrm{dm}{ }^{-3}$ ), high (98 to $196 \mathrm{mg} \mathrm{K} \mathrm{dm}^{-3}$ ), and very high (>196 $\mathrm{mg} \mathrm{K} \mathrm{dm}{ }^{-3}$ ) (Hardy et al. 2014). We divided soil-test $\mathrm{K}$ into four categories with our own label of expected nutrient requirement for forages of severely deficient $\left(<50 \mathrm{mg} \mathrm{K} \mathrm{dm}^{-3}\right.$ soil), moderately deficient (50 to $140 \mathrm{mg} \mathrm{K}$ $\mathrm{dm}^{-3}$ soil), sufficient (140 to $200 \mathrm{mg} \mathrm{K} \mathrm{dm}^{-3}$ soil), and excessive (>200 $\mathrm{mg} \mathrm{K} \mathrm{dm}^{-3}$ soil). Aggregated zones of similar concentration were outlined to highlight areas of concern (i.e., low [severely deficient] and very high [excessive] categories).

\section{Results and Discussion}

Soil texture varied among sampling points within each site. As a component of soil texture, sand concentration was greater and varied more among sampling points in the Coastal Plain location (middle $50 \%$ of data from 0.60 to $0.81 \mathrm{~g} \mathrm{~g}^{-1}$ ) than in the Piedmont (0.56 to $0.65 \mathrm{~g} \mathrm{~g}^{-1}$ ) and Blue Ridge (0.33 to $0.41 \mathrm{~g} \mathrm{~g}^{-1}$ ) locations (figure 3$)$. Sand concentration is an important soil physical attribute that controls water and nutrient flow and retention, as well as many other chemical and biological processes affecting nutrient distribution. Geospatially, greater sand concentration was found in the southern half of Pasture 3, the middle half of Pasture 4, and along the animal handling facility portions of Pastures 5, 6, and 7 in the Coastal Plain location (data not shown). More uniform geospatial distributions of sand were found in the Piedmont and Blue Ridge locations (data not shown). Therefore, the Coastal Plain location had soil textural variation of geospatial significance, but the other two locations did not. The Coastal Plain location is situated on the flood plain near the Neuse River, a landscape position known to cause large variations in texture (Deiss et al. 2017).

Soil Carbon Fractions. Total organic $\mathrm{C}$ varied more among sampling points in the Piedmont location (middle $50 \%$ of data from 17.2 to $29.5 \mathrm{~g} \mathrm{~kg}^{-1}$ ) than in the Coastal Plain (12.5 to $23.1 \mathrm{~g} \mathrm{~kg}^{-1}$ ) and Blue Ridge ( 33.8 to $43.8 \mathrm{~g} \mathrm{~kg}^{-1}$ ) locations (figure $3)$. Coefficient of variation was $37 \%, 67 \%$, and $16 \%$ in the Coastal Plain, Piedmont, and Blue Ridge locations, respectively. Skewed distribution of total organic C occurred particularly in the Piedmont location $(p<$ $0.001)$, as well as in the Coastal Plain location $(p=0.02)$, with several very high values exceeding normal distribution expectation. There were three hot spots of total organic $\mathrm{C}$ accumulation in the Piedmont location (data not shown). These spots were associated with recent winter hay-feeding stations. Unconsumed hay trampled by cattle near these feeding stations and feces deposition likely led to greatly elevated total organic C concentration. Spatial independence of soil organic $\mathrm{C}$ at the field level generally occurs at distances $>30 \mathrm{~m}$ (Klapwyk and Ketterings 2006; Deiss et al. 2017), so concentration zones were not considered random occurrences, but likely associated with management, e.g., hay-feeding stations. 


\section{Figure 3}

Box and whisker plots of (a) sand, (b) total organic carbon (C), (c) particulate organic C, and (d) soil-test biological activity from under pastures when sorted by Coastal Plain $(n=168)$, Piedmont $(n=116)$, and Blue Ridge $(n=28)$ locations in North Carolina. Shaded boxes represent the middle $50 \%$ of data with the center line as median. Error bars are 10th and 90 th percentile limits and circles represent range.

(a)

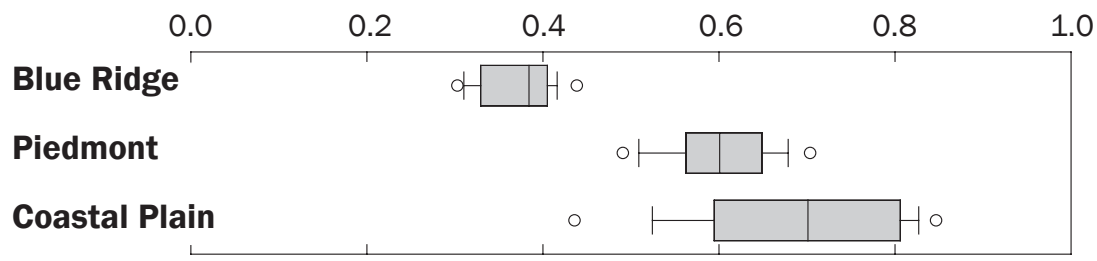

(b) Total organic carbon ( $\mathrm{g} \mathrm{kg}^{-1}$ soil)

$\begin{array}{lllllllllll} & 10 & 20 & 30 & 40 & 50 & 60 & 70 & 80 \\ \text { Blue Ridge } & & & \end{array}$

(c)

\section{Particulate organic carbon (g kg ${ }^{-1}$ soil)}

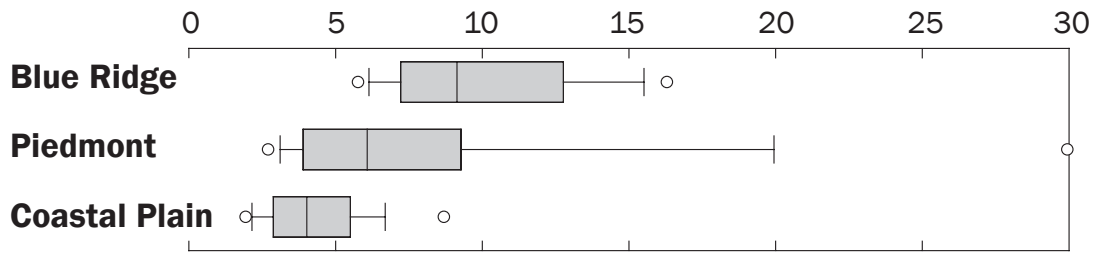

(d)

Soil-test biological activity (mg Co $\mathbf{~ C ~} \mathbf{~ k g}^{-\mathbf{1}} \mathbf{~ s o i l )}$ o to $\mathbf{~ d ~}$
Blue Ridge
Piedmont
Coastal Plain

Particulate organic C varied widely among sampling points at each location (figure 3). Particulate organic C distribution was similarly skewed with some higher than expected values in the Piedmont and Coastal Plain locations $(p<0.001)$ (figure 3). Although the box and whisker plot in figure 3 might suggest some skewness in the Blue Ridge location, the effect was not significant $(p=$ 0.09). The lack of difference may have been from the lower number of samples collected at this location. Like that of total organic C, particulate organic $\mathrm{C}$ varied more among sampling points in the Piedmont location (middle $50 \%$ of data from 3.9 to $9.3 \mathrm{~g} \mathrm{~kg}^{-1}$ ) than in the Coastal Plain (2.9 to $5.5 \mathrm{~g} \mathrm{~kg}^{-1}$ ) and Blue Ridge (7.2 to $12.8 \mathrm{~g} \mathrm{~kg}^{-1}$ ) locations. Coefficient of variation was $52 \%, 118 \%$, and $33 \%$ at Coastal Plain, Piedmont, and Blue Ridge locations, respectively. Grazed, perennial pastures can have elevated particulate organic $\mathrm{C}$ due to prolific rooting and surface residue accumulation, but also due to pasture age and forage type (Franzluebbers and Stuedemann 2002). Spatial dependence of particulate organic $\mathrm{C}$ was similar to that of total organic C (i.e., highly dependent at $<30 \mathrm{~m}$ distance) at a nearby Coastal Plain location (Deiss et al. 2017).

Soil-test biological activity averaged 314, 439, and $929 \mathrm{mg} \mathrm{CO}-\mathrm{C} \mathrm{kg}^{-1}$ soil $3 \mathrm{~d}^{-1}$ in Coastal Plain, Piedmont, and Blue Ridge locations, respectively. In general, the magnitude of soil-test biological activity was inversely related to sand concentration (figure 3). However, based on individual sampling points within each location, there was larger variation in soil-test biological activity than in sand concentration. Coefficient of variation was $40 \%, 47 \%$, and $21 \%$ among sampling points in the Coastal Plain, Piedmont, and Blue Ridge, respectively, for soil-test biological activity and was only $19 \%, 11 \%$, and $12 \%$, respectively, for sand concentration.

Although total organic $\mathrm{C}$ was a large factor in the magnitude of both particulate organic C and soil-test biological activity at each location, there were some unique relationships among these fractions (figure 4). Across all three locations, particulate organic C was approximately $15 \%$ of total organic $\mathrm{C}$ at the lowest organic matter levels. At the Piedmont location, the fraction of total organic $\mathrm{C}$ as particulate organic $\mathrm{C}$ rose to as high as $66 \%$ in $\mathrm{C}$-enriched hot spots associated with winter hay feeding. The relationship of increasingly greater fraction of particulate organic $\mathrm{C}$ per unit of total organic $\mathrm{C}$ was similar to that observed in multiple pastures in Georgia (Franzluebbers and Stuedemann 2002) and reflects the contribution of surface residue inputs and roots. Large surface residue inputs were expected from fouled hay and feces trampled into the soil around winter hay-feeding stations. As a fraction of total organic $\mathrm{C}$ in tall fescue fields of Georgia, North Carolina, Virginia, and West Virginia, soil-test biological activity was $\sim 1 \%$ and had a mild, positive association (Franzluebbers et al. 2018). Variation in soil-test biological activity was considered of greater importance to soil health and fertility than that of total organic C (Franzluebbers 2016). This small, active portion of organic matter was also more closely related with corn grain yield response to applied $\mathrm{N}$ across 17 sites in the Midwest United States (Yost et al. 2018).

Soil-test biological activity was a greater fraction of total organic $\mathrm{C}$ in the Blue Ridge location (24 $\pm 6 \mathrm{mg} \mathrm{CO}_{2}-\mathrm{C} \mathrm{g}^{-1}$ total organic $\mathrm{C}$ [mean \pm standard deviation]) than in the Coastal Plain and Piedmont locations (17 \pm 


\section{Figure 4}

Relationship of (a) soil-test biological activity and (b) particulate organic carbon (POC) to total organic C (TOC) across samples from pastures in Coastal Plain, Piedmont, and Blue Ridge locations in North Carolina. ${ }^{\star \star \star}$ indicates significance at $p \leq 0.001$. ns is not significant.

(a)

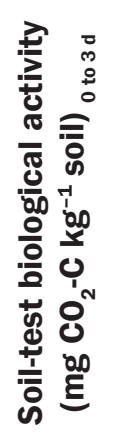

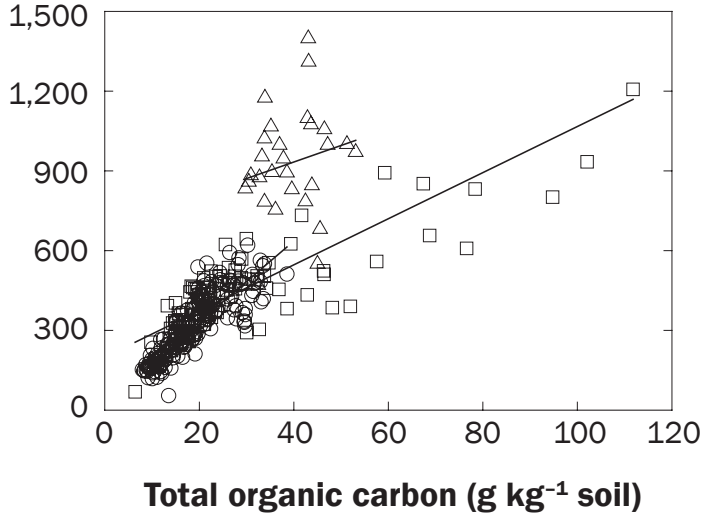

Legend

$\triangle$ Blue Ridge

$0.04 \mathrm{~ns}$

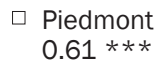

(b)

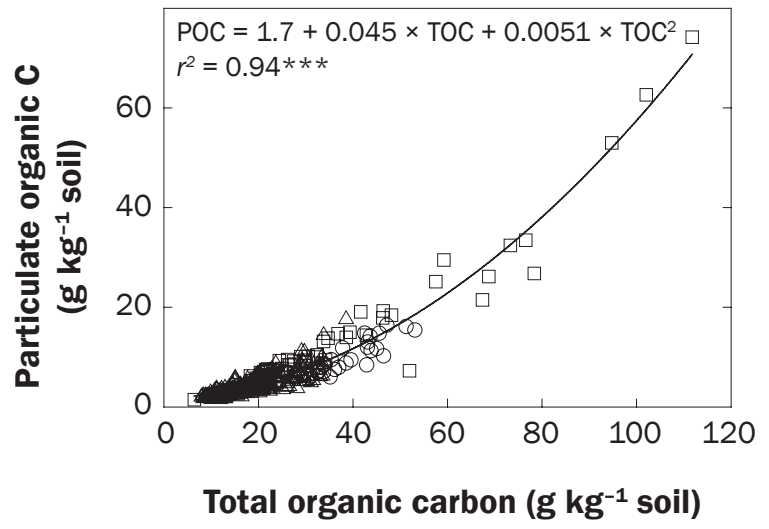

$4 \mathrm{mg} \mathrm{CO}_{2}-\mathrm{C} \mathrm{g} \mathrm{g}^{-1}$ total organic $\mathrm{C}$; figure 4), suggesting that the cooler climate or greater fine fraction of soil in the Blue Ridge may have led to proportionally greater biological activity of total organic C. However using a regression approach, there was a greater rate of change in soil-test biological activity per unit change in total organic $\mathrm{C}$ in the Coastal Plain (15.2 mg CO- $\mathrm{C} \mathrm{g}^{-1}$ total organic $\mathrm{C}$ ) than in the Piedmont $\left(8.7 \mathrm{mg} \mathrm{CO}_{2}-\mathrm{C} \mathrm{g}^{-1}\right.$ total organic $\mathrm{C}$ ) and Blue Ridge locations (6.2 $\mathrm{mg}$ $\mathrm{CO}_{2}-\mathrm{C} \mathrm{g}^{-1}$ total organic $\mathrm{C}$ ). This result suggests that if one assumes recent management was responsible for changes in total organic C, then soil-test biological activity would have been more enhanced with management in the Coastal Plain than other locations (per unit change in total organic $\mathrm{C}$ ). Changes in soil-test biological activity are of consequence on dynamics of nutrient cycling, particularly N (Franzluebbers 2016, 2018).

Soil-test biological activity had significant concentration in geospatially explicit zones in the Coastal Plain and Piedmont locations, but not the Blue Ridge location (figure 5). At the Coastal Plain location, high soil-test biological activity was concentrated in the northern half of Pasture 2 (which had lower sand concentration than the southern half), the eastern and western thirds of Pasture 3 (one of which had lower sand concentration and one that had high sand concentration but an area with historical winter hay feeding), the northern half of Pasture 4 (which had lower sand concentration and was lower in elevation), and the middle third of Pasture 7 (which had high sand concentration but an area with historical winter hay feeding). At the Piedmont location, high soil-test biological activity was concentrated in three recent winter hay-feeding stations. Enhanced soil-test biological activity in hot spots was obviously a function of significant residual hay and feces that served as C substrates, and this effect occurred in the Coastal Plain location independent of variable clay concentration that often limits $\mathrm{C}$ availability and stability (Merckx et al. 1985).

Soil Nitrogen Fractions. Like that of total organic $\mathrm{C}$, total soil $\mathrm{N}$ varied more among sampling points in the Piedmont location (middle $50 \%$ of data from 1.33 to $2.19 \mathrm{~g}$ $\mathrm{kg}^{-1}$ ) than in the Coastal Plain (1.14 to 2.09 $\mathrm{g} \mathrm{kg}^{-1}$ ) and Blue Ridge (3.03 to $4.00 \mathrm{~g} \mathrm{~kg}^{-1}$ ) locations (figure 6). Coefficient of variation was $38 \%, 73 \%$, and $17 \%$ in the Coastal Plain, Piedmont, and Blue Ridge locations, respectively. Soil C:N ratio was different among locations, following the order $11.1 \pm 0.6$ (mean \pm standard deviation) in the Coastal Plain $<13.1 \pm 1.5$ in the Piedmont $>10.9$ \pm 0.7 in the Blue Ridge. Soil C: $\mathrm{N}$ ratio was greater in the Piedmont than the other two regions for some reason other than those samples with elevated soil organic matter due to winter hay feeding, as there was no shift in $\mathrm{C}: \mathrm{N}$ ratio with regard to overall level of total organic C. Soil C:N ratio of nonforested surface soils is generally $\sim 12$, whereas $\mathrm{C}: \mathrm{N}$ ratio of forested soils is often near 20 (Brady and Weil 1999). The legacy from previous timber land use from the Piedmont location ( 30 years ago) may have contributed to elevated $\mathrm{C}: \mathrm{N}$ ratio.
Particulate organic $\mathrm{N}$ followed patterns similar to that of total soil $\mathrm{N}$ and of particulate organic C. Particulate organic N varied more among sampling points in the Piedmont location (middle $50 \%$ of data from 0.15 to $0.32 \mathrm{~g} \mathrm{~kg}^{-1}$ ) than in the Coastal Plain ( 0.19 to $0.52 \mathrm{~g} \mathrm{~kg}^{-1}$ ) and Blue Ridge (0.45 to $0.81 \mathrm{~g} \mathrm{~kg}^{-1}$ ) locations (figure 6). Coefficient of variation was even greater than with particulate organic $\mathrm{C}$ at $63 \%, 156 \%$, and $40 \%$ at Coastal Plain, Piedmont, and Blue Ridge locations, respectively. Decomposition of particulate organic $\mathrm{N}$ with time by soil microbial activity can provide a significant and steady supply of $\mathrm{N}$ for forage plants.

Residual soil $\mathrm{NH}_{4}^{+}$concentration was skewed in distribution in Coastal Plain and Piedmont locations $(p<0.001)$, but not in the Blue Ridge location (figure 6). Residual soil $\mathrm{NO}_{3}^{-}$concentration was skewed in distribution at all locations. Residual soil $\mathrm{NH}_{4}^{+}$ concentration was moderate, and residual soil $\mathrm{NO}_{3}^{-}$concentration was relatively low at all three locations. The middle $50 \%$ of data for $\mathrm{NH}_{4}^{+}$concentration was from 9 to $17 \mathrm{mg} \mathrm{kg}^{-1}$ in the Coastal Plain, from 8 to $14 \mathrm{mg} \mathrm{kg}^{-1}$ in the Piedmont, and 17 to $22 \mathrm{mg} \mathrm{kg}^{-1}$ in the Blue Ridge. Ammonium concentration $>5 \mathrm{mg} \mathrm{kg}^{-1}$ as a general baseline was likely due to drying of soil across all samples and enhanced soil organic matter in some cases. The middle $50 \%$ of data for $\mathrm{NO}_{3}{ }^{-}$concentration was from 3 to $7 \mathrm{mg} \mathrm{kg}^{-1}$ in the Coastal Plain, 1 to $5 \mathrm{mg} \mathrm{kg}^{-1}$ in the Piedmont, and 4 to $14 \mathrm{mg} \mathrm{kg}^{-1}$ in the Blue Ridge. Low residual inorganic $\mathrm{N}$ concentration was expected, as perennial pastures have 


\section{Figure 5}

Geospatial distribution of soil-test biological activity $\left(\mathrm{mg} \mathrm{CO}_{2}-\mathrm{C} \mathrm{kg}^{-1}\right.$ soil $\left.3 \mathrm{~d}^{-1}\right)$ at three locations with grazed pastures in the Coastal Plain, Piedmont, and Blue Ridge regions of North Carolina. Low and very high regions are delineated with thin and thick lines, respectively. Increasingly greater size of triangle relates to increasingly greater concentration.
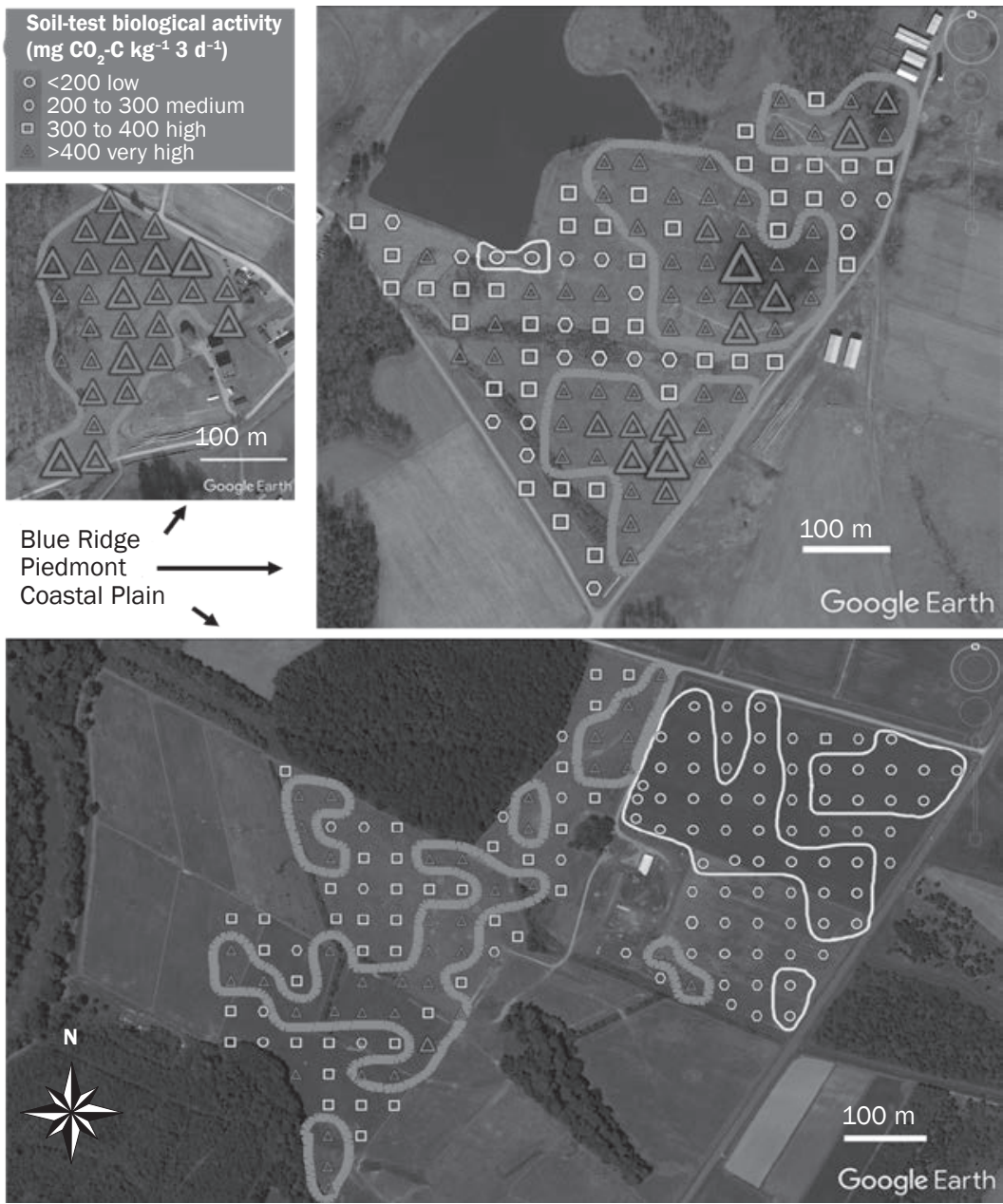

extensive root systems to absorb soluble $\mathrm{N}$ and forage stands are often of mixed cool and warm season forages that promote active $\mathrm{N}$ uptake throughout the year. On average, the proportion of total soil $\mathrm{N}$ as soil $\mathrm{NH}_{4}^{+}$ and $\mathrm{NO}_{3}^{-}$was $3.7 \mathrm{mg}$ inorganic $\mathrm{N} \mathrm{g}^{-1}$ total soil $\mathrm{N}$ across all locations $(p<0.001)$. These results suggest that only a small reflection of enhanced organic $\mathrm{N}$ would be detectable in the residual inorganic $\mathrm{N}$ fraction.

Like that of soil-test biological activity, total soil $\mathrm{N}$ had significant geospatial concentration areas in the Coastal Plain and Piedmont locations, but not the Blue Ridge location (figure 7). Areas of high concentration generally corresponded to those for soil-test biological activity. The arbitrary boundaries for total soil $\mathrm{N}$ at 1 , 2 , and $3 \mathrm{~g} \mathrm{~kg}^{-1}$ led to reduced area for the very high category, but nearly the same target areas corresponding to historical winter hay-feeding stations in all cases and low sand concentration in some cases.

Soil-Test Phosphorus and Cations. Soiltest $\mathrm{P}$ was highly variable at all three locations, but more dramatically in the Coastal Plain and Piedmont locations than the Blue Ridge location (figure 8). Coefficient of variation was $80 \%, 113 \%$, and $52 \%$ at Coastal Plain, Piedmont, and Blue Ridge locations, respectively. The middle $50 \%$ of data was from 80 to $264 \mathrm{mg} \mathrm{dm}^{-3}$ at the Coastal Plain location, 27 to $112 \mathrm{mg} \mathrm{dm}^{-3}$ at the Piedmont location, and 52 to $108 \mathrm{mg} \mathrm{dm}^{-3}$ at the Blue Ridge location. Soil-test $\mathrm{P}$ is considered sufficient from 84 to $120 \mathrm{mg} \mathrm{dm}^{-3}$ for both cool and warm-season forages in North Carolina (Hardy et al. 2014).
Soil-test $\mathrm{P}$ concentration was considered moderately or severely deficient in $27 \%$ of the Coastal Plain location, $72 \%$ of the Piedmont location, and $57 \%$ of the Blue Ridge location (figure 9). Soil-test $\mathrm{P}$ was in the sufficiency range in only $17 \%$ of the area in the Coastal Plain, 4\% of the area in the Piedmont location, and $36 \%$ of the pasture in the Blue Ridge location. In contrast, $56 \%$ of the area in the Coastal Plain was considered excessive in extractable P. About half of this enriched area had soil-test P levels that exceeded twice the sufficiency level. The highest concentrations were centered at historical winter hay-feeding stations in Pastures 3 to 7 at the Coastal Plain location. High soil-test $\mathrm{P}$ also extended to larger areas with high sand concentration with little clay buffering capacity to adsorb $\mathrm{P}$ and make it less available.

In the Piedmont and Blue Ridge regions, the area considered excessive in soil-test $\mathrm{P}$ was $24 \%$ and $7 \%$, respectively. Soil-test $\mathrm{P}$ $>120 \mathrm{mg} \mathrm{dm}^{-3}$ is considered excessive of plant response and could threaten water quality if leached or removed via runoff. Although only $11 \%$ of the pasture area in the Piedmont had soil-test $\mathrm{P}$ level that exceeded twice the sufficiency level, the concentration was $332 \pm 70 \mathrm{mg} \mathrm{dm}^{-3}$ and clearly linked to winter hay-feeding stations (figure 9).

At all locations, only a narrow percentage of the pastures was in an ideal sufficiency range for soil-test $\mathrm{P}$ (i.e., 84 to $120 \mathrm{mg} \mathrm{dm}^{-3}$ ). A majority of the pasture was excessive in the Coastal Plain location, and majority areas were deficient in the Piedmont and Blue Ridge locations. These results point to a need for better distribution of nutrients in grazed pastures of the region. Soil sampling strategies should be tailored to unique management conditions on each farm.

Soil-test K was also highly variable at all three locations with coefficient of variation of $86 \%, 109 \%$, and $50 \%$ at Coastal Plain, Piedmont, and Blue Ridge locations, respectively (figure 8 ). The middle $50 \%$ of data was from 99 to $199 \mathrm{mg} \mathrm{dm}^{-3}$ at the Coastal Plain location, 75 to $247 \mathrm{mg} \mathrm{dm}^{-3}$ at the Piedmont location, and 209 to $498 \mathrm{mg} \mathrm{dm}^{-3}$ at the Blue Ridge location. Soil-test K values from 140 to $200 \mathrm{mg} \mathrm{dm}^{-3}$ are considered sufficient for both cool- and warm-season forages in North Carolina (Hardy et al. 2014).

At the Coastal Plain location, soil-test K was considered moderately to severely deficient in $48 \%$ of the area, sufficient in $27 \%$ 
of the area, and excessive in $25 \%$ of the area (figure 10). Like that for soil-test P, the areas with $\mathrm{K}$ enrichment were near the central livestock handling facility in Pastures 4 and 5 , as well as in Pastures 2 and 3, in which winter-feeding stations were placed along the eastern fence as a tractor travel corridor.

At the Piedmont location, soil-test K was moderately to severely deficient in 59\% of the area, sufficient in $14 \%$ of the area, and excessive in $27 \%$ of the area (figure 10). The location and total area of $\mathrm{K}$ enrichment were essentially the same as for P enrichment. The area of severe $\mathrm{K}$ deficiency was considerably smaller than that of $\mathrm{P}$ deficiency, but the areas overlapped.

At the Blue Ridge location, soil-test $\mathrm{K}$ was deficient in only $7 \%$ of the pasture, sufficient in $14 \%$ of the pasture, and excessive in $79 \%$ of the pasture (figure 10). The excessive $\mathrm{K}$ concentration contrasted with the majority of the pasture as moderately P deficient.

Associations among Soil Properties. With a large number of observations at each site, many statistically significant associations occurred, but we isolated those associations that were strong $(0.8<|r|<0.9)$ and strongest $(|r|>0.9)$. Among the 168 samples collected at the Coastal Plain location, strongest associations were for (1) total organic C with total soil $\mathrm{N}$; (2) particulate organic C with particulate organic $\mathrm{N}$; (3) cation exchange capacity with total organic $\mathrm{C}$, total soil N, extractable $\mathrm{Ca}$, and extractable $\mathrm{Mg}$; (4) soil $\mathrm{pH}$ with base saturation; and (5) extractable Ca with extractable Mg. Among the 116 samples collected at the Piedmont location, strongest associations included all those identified for the Coastal Plain, except for cation exchange capacity with total organic $\mathrm{C}$ and total soil N. Additionally, the Piedmont location had strongest associations for total soil $\mathrm{N}$ with particulate organic $\mathrm{C}$ and $\mathrm{N}$ and total organic $\mathrm{C}$ with particulate organic $\mathrm{C}$ and N. Among the 28 samples collected at the Blue Ridge location, strongest associations included most of those identified for the Piedmont location, but also included soil acidity with soil $\mathrm{pH}$ and base saturation and residual soil $\mathrm{NO}_{3}^{-}$with residual inorganic $\mathrm{N}$. Most of these associations were stoichiometric between $\mathrm{C}$ and $\mathrm{N}$ of total or particulate organic fractions or among various base cations with strong physicochemical nature. Cation exchange capacity can be largely influenced by differences in organic matter, given the same concentration of clay (Brady

\section{Figure 6}

Box and whisker plots of (a) total soil nitrogen (N), (b) particulate organic N, (c) soil ammonium $(\mathrm{NH}-\mathrm{N})$, and (d) soil nitrate (NO $-\mathrm{N})$ from under pastures when sorted by Coastal Plain $(n=$ 168), Piedmont $(n=116)$, and Blue Ridge $(n=28)$ locations in North Carolina. Shaded boxes represent the middle $50 \%$ of data with the center line as median. Error bars are 10th and 9oth percentile limits and circles represent range.

(a)

Total soil nitrogen ( $\mathrm{g} \mathrm{kg}^{-1}$ soil)

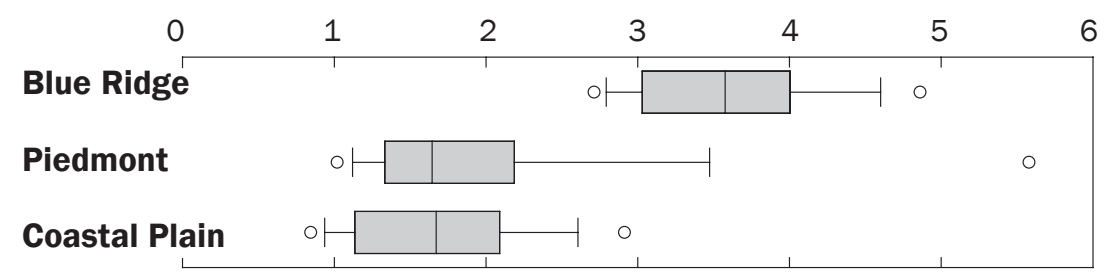

(b)

\section{Particulate organic nitrogen (g kg $\mathrm{kg}^{-1}$ soil)}

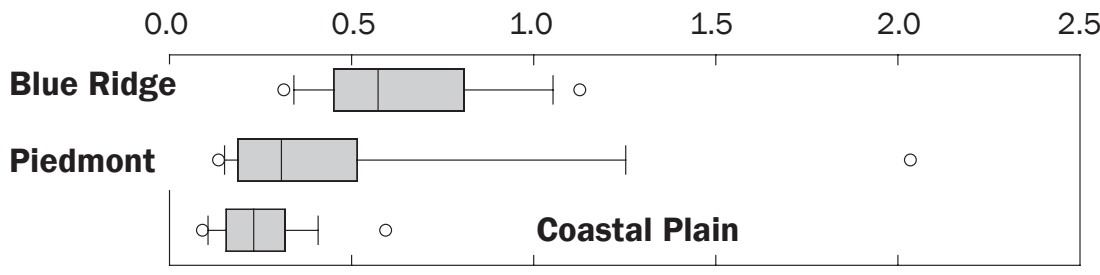

(c) Soil ammonium (mg $\mathrm{NH}_{4}-\mathrm{N} \mathrm{kg}^{-1}$ soil)

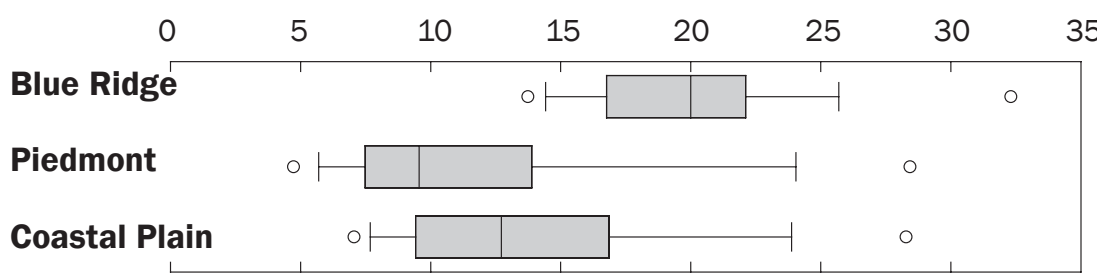

(d) Soil nitrate (mg NO $\mathrm{N}_{3}-\mathrm{N} \mathrm{kg}^{-1}$ soil)

Blue Ridge

and Weil 1999). Particulate organic C and N are often a relatively stable portion of total $\mathrm{C}$ and $\mathrm{N}$ (Franzluebbers and Stuedemann 2002). At the Blue Ridge location, residual soil $\mathrm{NO}_{3}^{-}$was the dominant influence on residual inorganic $\mathrm{N}\left(\mathrm{NO}_{3}^{-}+\mathrm{NH}_{4}^{+}\right)$.

We evaluated the association of the four primary properties evaluated in this study (i.e., total soil $\mathrm{N}$, soil-test biological activity, soil-test $\mathrm{P}$, and soil-test $\mathrm{K}$ ) against each other. Total soil $\mathrm{N}$ had a strong association with soil-test biological activity in the
Coastal Plain and Piedmont, but not in the Blue Ridge. Total soil $\mathrm{N}$ had no association with soil-test $\mathrm{P}$ and weak association with soil-test $\mathrm{K}$ in the Coastal Plain, strong association with both soil-test $\mathrm{P}$ and $\mathrm{K}$ in the Piedmont, and weak association with soiltest $\mathrm{P}$ and no association with soil-test $\mathrm{K}$ in the Blue Ridge. Soil-test biological activity was weakly associated with soil-test P and K in the Coastal Plain and Piedmont, but had no association with other soil properties in the Blue Ridge. Soil-test P had strong asso- 


\section{Figure 7}

Geospatial distribution of total soil nitrogen ( $\mathrm{g} \mathrm{N} \mathrm{kg}^{-1}$ soil) at three locations with grazed pastures in the Coastal Plain, Piedmont, and Blue Ridge regions of North Carolina. Low and very high regions are delineated with thin and thick lines, respectively.
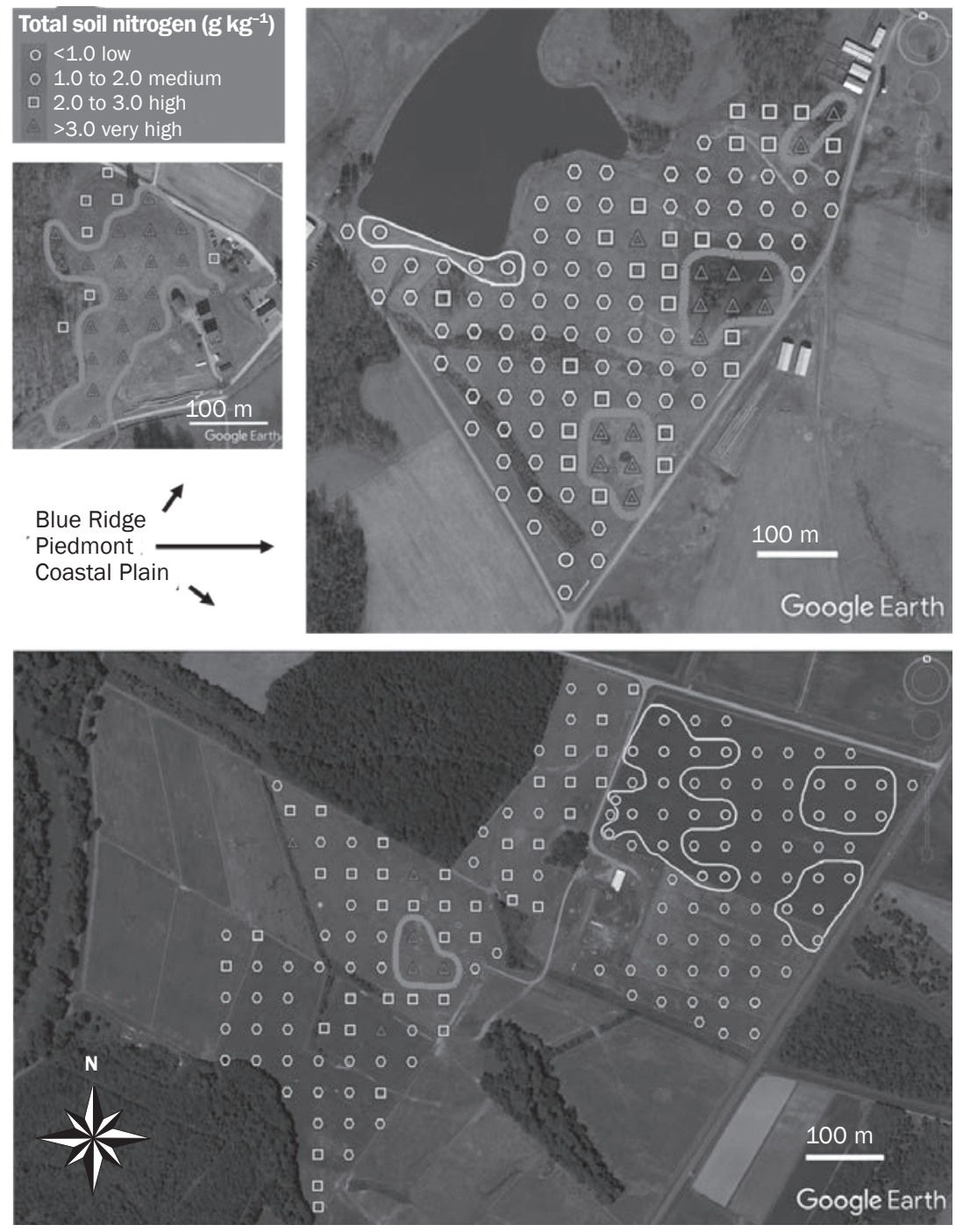

ciation with soil-test $\mathrm{K}$ in the Piedmont, but only weak association with soil-test $\mathrm{K}$ in the Coastal Plain and Blue Ridge. The lack of consistent relationships among these four soil properties across physiographic regions suggested that all four properties could provide unique information, and therefore, should be measured for complete assessment to identify unique soil conditions.

Soil $\mathrm{NH}_{4}^{+}$and $\mathrm{NO}_{3}^{-}$and soil-test $\mathrm{P}$ and $\mathrm{K}$ had more significant relationships with other soil properties at the Piedmont location than other locations. This may have been due to the continuous and long-standing practice of winter hay-feeding stations placed near the farm road at the top of the landscape that brought in organic nutrients from hay.
Animal consumption, defecation, and spoilage of uneaten hay at these locations was a key influence on nutrient accumulations relative to the remainder of the pastures that were very low in inorganic nutrient concentrations. Extractable $\mathrm{Ca}$ and $\mathrm{Mg}$ were closely related with a wide diversity of other soil variables at all three locations. Both organic and inorganic soil properties were a part of this set of variables related with $\mathrm{Ca}$ and $\mathrm{Mg}$ concentrations, suggesting that overall soil fertility was interlinked between a diversity of organic and inorganic variables.

Across all three locations $(n=312)$, all soil properties measured (except humic matter) were related with at least 11 other soil properties (table 2). Total soil $\mathrm{N}$ had the most number of significant $(p<0.001)$ associations, which was with 20 other variables, but not acidity and humic matter. Other variables that were significantly associated with at least 18 variables included total organic $\mathrm{C}$, density, residual inorganic $\mathrm{N}$, soil-test $\mathrm{K}$, extractable $\mathrm{Ca}$, cation exchange capacity, base saturation, extractable $\mathrm{Mg}$, extractable $\mathrm{Zn}$, soil-test biological activity, residual soil $\mathrm{NO}_{3}^{-}$, and residual soil $\mathrm{NH}_{4}^{+}$. Using the highest average absolute value of the correlation coefficient $(r)$ among the 22 variables as criterion resulted in the top 10 variables with strongest correlation (in ranked order) of total soil $\mathrm{N}$, total organic $\mathrm{C}$, cation exchange capacity, extractable $\mathrm{Mg}$ and $\mathrm{Ca}$, particulate organic $\mathrm{C}$ and $\mathrm{N}$, soil-test biological activity, residual inorganic $\mathrm{N}$, and density. Those variables least correlated with others were humic matter, extractable S, acidity, extractable $\mathrm{Mn}$, soil-test $\mathrm{P}$, and sand concentration.

Across locations and among the four primary properties of interest in this study, total soil $\mathrm{N}$ was correlated strongest with soil-test biological activity $(r=0.78, p<0.001)$ and least with soil-test $\mathrm{P}(r=0.20, p<0.001)$. This confirmed the strong association between total soil $\mathrm{N}$ and soil-test biological activity at each individual location, but the disparate association between total soil $\mathrm{N}$ and soil-test P. Soil-test biological activity was not significantly associated with soil-test $\mathrm{P}$ across locations, and soil-test $\mathrm{P}$ and $\mathrm{K}$ were only weakly associated $(r=0.48, p<0.001)$. Therefore, soil fertility in pastures should be evaluated with a combination of inorganic and organic soil-test indicators. We suggest that in addition to soil-test $\mathrm{P}$ and $\mathrm{K}$ as key variables to measure (due to specific relationship with plant requirements and widespread fertilizer availability), total soil $\mathrm{N}$ and soil-test biological activity be considered for a minimum data set in pastures. Total soil $\mathrm{N}$ reveals the capacity of $\mathrm{N}$ supply. Soil-test biological activity reveals a more specific likelihood of organic $\mathrm{N}$ release (as well as potential relationship with several other nutrients like P, S, $\mathrm{Zn}$, and other micronutrients), and is a general indication of soil health (Franzluebbers 2016).

\section{Nonuniform Nutrient Distribution.} Nutrient concentrations from a statistical perspective were not randomly distributed on the landscape, but rather large values were concentrated in specific zones. Soiltest $\mathrm{P}$ and $\mathrm{K}$ were clearly concentrated in areas that could be attributed to historical management of pastures, specifically win- 
ter hay-feeding stations at Coastal Plain and Piedmont locations (figures 9 and 10). Previous studies have shown that cattle spend more time in areas near water and shade than in other areas of the pasture. In a Colorado study, cattle spent $27 \%$ of time on only $2.5 \%$ of the land area (Augustine et al. 2013). In small pastures in Iowa, cattle spent a greater proportion of time in areas with streamside woods than in open areas (Bear et al. 2012). In larger pastures, disproportional time spent in shade diminished. When grazing bahiagrass in an open pasture setting in Florida, greater loafing and less grazing occurred than in a silvopasture setting (Karki and Goodman 2007). Most pastures in North Carolina and surrounding states are relatively small, e.g., the average pasture area per farm is only 19 ha. Therefore, nonuniform nutrient distribution can be expected.

Nutrients in grazed pastures of North Carolina were unevenly distributed in different ways depending on location in this study. Some causes of this nonuniform distribution were attributable to feces deposition and hay spoilage in repeated feeding areas of the pasture (e.g., extreme cases of this effect in the Piedmont location). Other factors causing nonuniform distribution of nutrients were placement of water tanks for drinking, shade for lounging, and fencelines and gates for controlling movement of livestock (e.g., in Paddocks 2, 3, and 4 at the Coastal Plain location). Elevated concentration of inorganic and organic nutrients near water and/or shade sources of small research pastures has been observed in Iowa (West et al. 1989), Georgia (Franzluebbers et al. 2000; Schomberg et al. 2000), and Florida (Mathews et al. 1994; Sigua and Coleman 2006). Permanent placement of fencing, shade, water, and feeding stations in perennial pastures contributes to nutrient accumulation zones caused by livestock behavior. If fertilizers are applied to small and irregularly shaped pastures, application vehicles may also preferentially distribute nutrients based on available traffic lanes, which could further exacerbate nutrient concentration. These data clearly show that livestock producers should become more aware of the important role they can play in devising strategies to overcome inherent nutrient concentration effects from animal behavior and permanent paddock arrangements. Temporary fencing and portable water sources may be key strategies to more effectively utilize nutrients

\section{Figure 8}

Box and whisker plots of (a) extractable phosphorus (P), (b) potassium (K), (c) calcium (Ca), and (d) magnesium $(\mathrm{Mg})$ from under pastures when sorted by Coastal Plain $(n=168)$, Piedmont $(n$ $=116)$, and Blue Ridge $(n=28)$ locations in North Carolina. Shaded boxes represent the middle $50 \%$ of data with the center line as median. Error bars are 10th and 9oth percentile limits and circles represent range.

(a)

Extractable phosphorus ( $\mathrm{mg} \mathrm{dm}^{-3}$ soil)

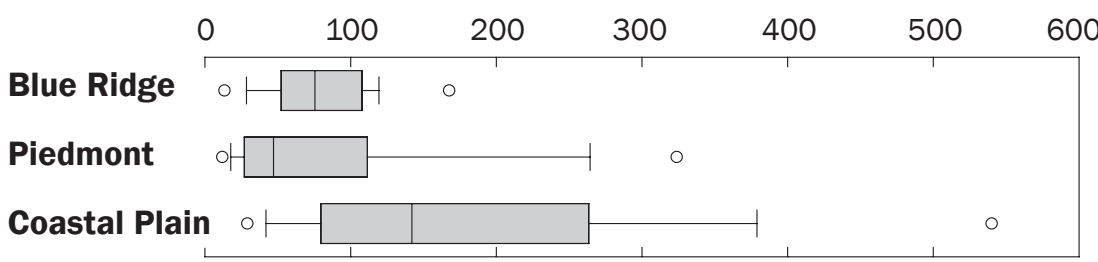

(b)

Extractable potassium ( $\mathrm{mg} \mathrm{dm}^{-3}$ soil)

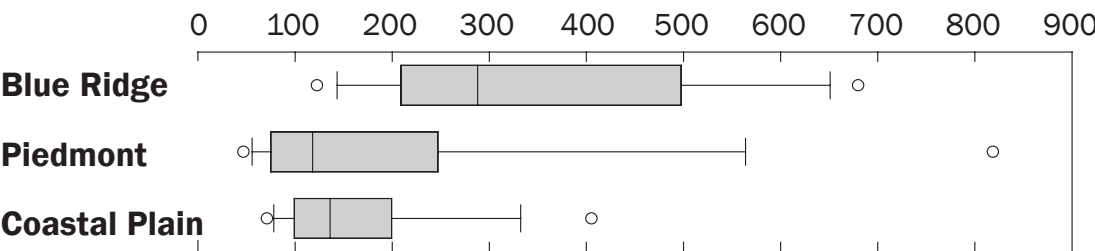

(c)

Extractable calcium ( $\mathrm{mg} \mathrm{dm}^{-3}$ soil)

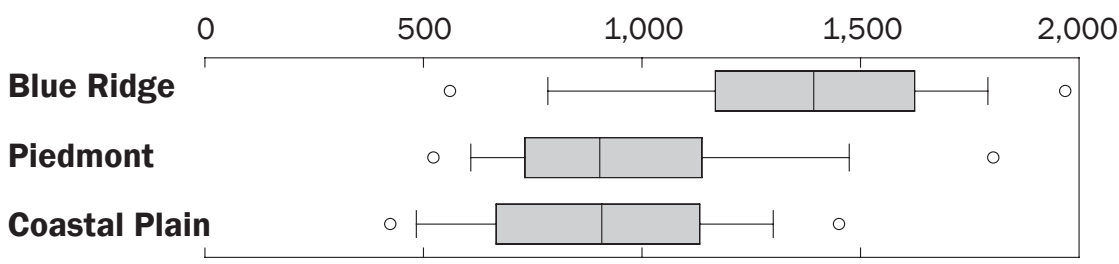

(d)

Extractable magnesium ( $\mathrm{mg} \mathrm{dm}^{-3}$ soil)

\begin{tabular}{|c|c|c|c|c|c|c|c|}
\hline 0 & 100 & 200 & 300 & 400 & 500 & 600 & 700 \\
\hline Blue Ridge & & $\circ$ & & H & 1 & $\circ$ & \\
\hline ledmont & & $\circ$ & & . & & -1 & ( \\
\hline oastal Plain & $\circ \vdash$ & & & & & & \\
\hline
\end{tabular}

already present in a pasture, as well as to avoid potential environmental damage with high concentration of nutrients in soil.

We hypothesized that surface-soil nutrients would be spatially distributed based on livestock management variables, and concentration zones for soil-test biological activity (figure 5), total soil $\mathrm{N}$ (figure 7), soil-test $\mathrm{P}$ (figure 9), and soil-test K (figure 10) confirmed this hypothesis in at least two of three locations for each variable. Each location had unique landscape characteristics, but key livestock management issues of drinking water location and winter hay-feeding stations were consistently influential factors affecting soil nutrient distribution. Unique landscape features will occur for many livestock farms throughout the state and region, and so further investigation of nutrient distribution on private farms is warranted. We plan to report results from several private farms in the same physiographic regions of North Carolina as a next step.

Irrespective of location, some key management recommendations can be made for improving nutrient distribution in perennial pastures in the region. First, sampling soil in spatially explicit zones near preferential 


\section{Figure 9}

Extractable phosphorus $(P)$ concentration at three sampling locations with grazed pastures in the Coastal Plain, Piedmont, and Blue Ridge regions of North Carolina. Low and very high regions are delineated with thin and thick lines, respectively. Increasingly greater size of triangle relates to increasingly greater concentration.
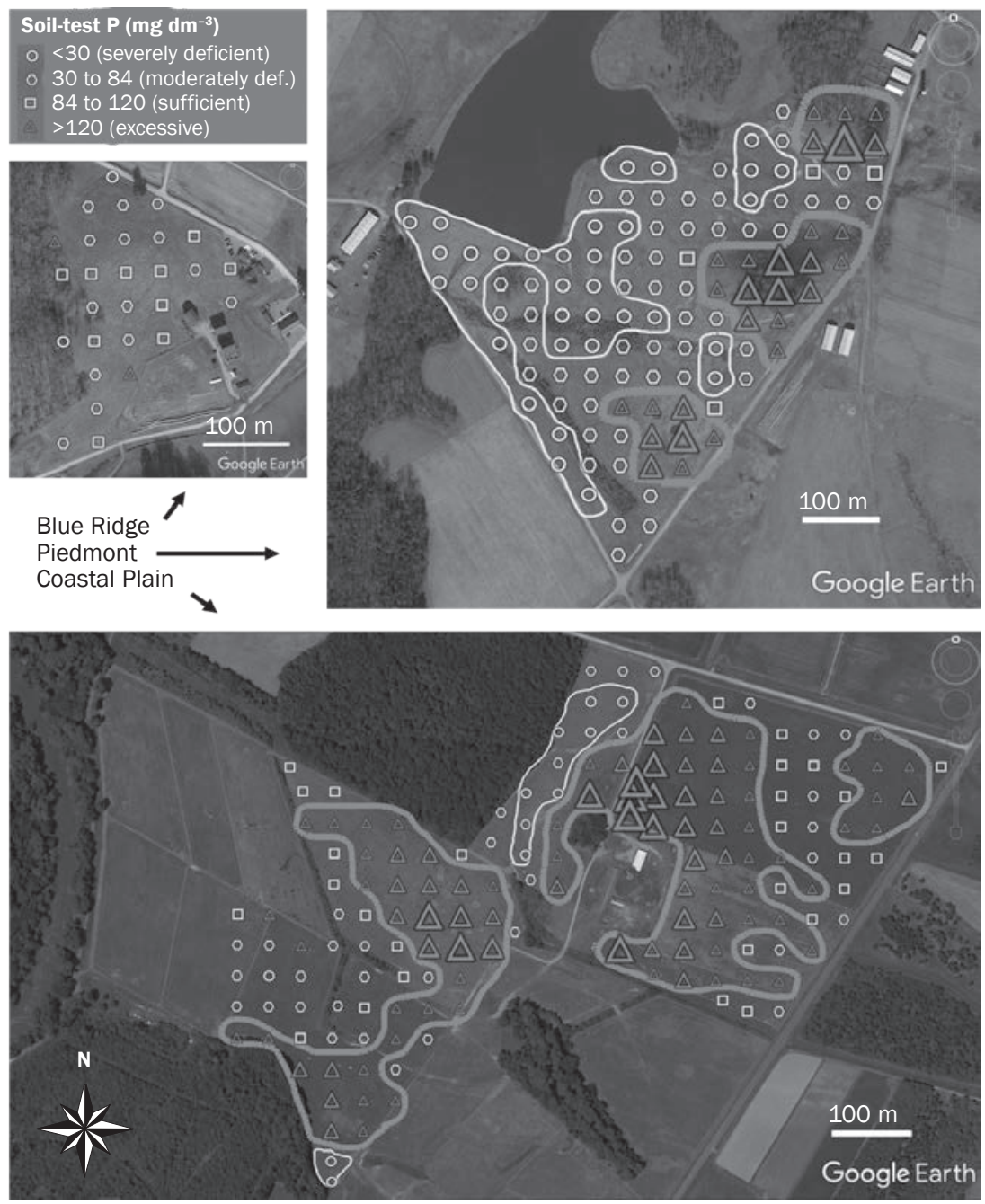

livestock congregation areas should either be avoided or considered separately from sampling zones that are potentially more uniformly grazed and impacted by livestock. Knowing the difference in nutrient concentrations can allow producers to make more informed decisions on whether external nutrients are even required or how they can be differentially distributed onto pastures. Fertilization of pastures can be avoided in those zones that cannot be rehabilitated from livestock-induced nutrient loading, for whatever logical and/or physical reasons. When possible, winter hay-feeding stations and portable water sources could be placed in different parts of the pasture so that organic sources of feces and hay waste can be used to obtain more uniform distribution of nutri- ents over the long-term (Schomberg et al. 2000). Unrolling hay in specific portions of the pasture to concentrate livestock during winter feeding could be a viable approach to distribute nutrients (unused hay and feces in these zones can be a valuable source of organic nutrients) and possibly to rehabilitate portions of a pasture through trampling and seed recruitment (although research is yet incomplete as to its broader effects on pasture productivity)

When possible, permanent heavy use areas by livestock could be positioned on a part of the landscape with as long of a water flow path to streams and rivers as possible so that residual forage mass and naturalized woody vegetation areas can filter and absorb nutrients prior to potential entry into receiving water bodies (Sanderson et al. 2010). Further, subdividing pastures into smaller paddocks with temporary fencing could more effectively utilize available forage and equalize feces distribution across the landscape, which could potentially result in more uniform soil nutrient distribution, although limited data are available to support this approach (Nelson 2012). In a paired-pasture approach, soil loss, runoff volume, and total $\mathrm{N}$ loss were reduced with rotational stocking compared with continuous stocking in Ohio (Owens et al. 1997; Owens and Shipitalo 2009).

Integrated soil nutrient data from inorganic and organic indicators measured in this study also illustrate the strong influence of soil organic matter as a controlling factor of soil fertility. Total organic $\mathrm{C}$ and $\mathrm{N}$ were highly related with many traditional soil-testing indicators, such as cation exchange capacity, soil-test $\mathrm{K}$, extractable $\mathrm{Ca}$ and $\mathrm{Mg}$, and residual inorganic $\mathrm{N}$. The supply of $\mathrm{N}$ to forages can be largely cycled from steady-state decomposition of organic matter. If soil-test biological activity is high enough through good grazing management with rotational stocking and maintenance of balanced fertility with organic manure sources (e.g., poultry litter application and distributed dung deposition by grazing cattle), then the need for external $\mathrm{N}$ application can be significantly reduced to maintain productivity and enhance return on fertilizer investment (Franzluebbers et al. 2018).

\section{Summary and Conclusions}

A variety of nutrients in the surface $10 \mathrm{~cm}$ of soil were statistically variable and geospatially concentrated within zones of perennial pastures in two of the three locations in North Carolina. Geospatial distribution of nutrients was mainly attributed to winter hay-feeding stations that caused animal congregation leading to organic nutrient deposition from defecation and hay trampling and spoilage. One location indicated the presence of a historical winter hay-feeding station that remained elevated in soil-test $\mathrm{P}$ due to its immobile nature, whereas the mobile soil-test $\mathrm{K}$ and organic indicators had more uniform distribution after the hay-feeding station was removed. Placement of drinking water was another factor that contributed to nutrient enrichment. Low soil-test $\mathrm{K}$ was attributed in one case to frequent hay removal. Both organic (i.e., soil-test biological activity and total soil $\mathrm{N}$ ) and inorganic 
(soil-test $\mathrm{P}$ and $\mathrm{K}$ ) soil-test indicators are suggested as a comprehensive strategy to assess soil nutrient distribution in perennial pastures. Management of hay-feeding stations and sampling soil in zones for nutrients with subsequent fertilization decisions are two strategies to improve resource efficiency. These results reveal the problems and opportunities for better nutrient distribution in grazed perennial pastures in the southeastern United States.

\section{Acknowledgements}

We thank Ellen Leonard and April Schaeffer (technicians at North Carolina State University in Raleigh, North Carolina) and Ashton Mizelle and Erin Silva (lab assistant and technician with USDA Agricultural Research Service [ARS] in Raleigh, North Carolina) for sound technical support. We also thank Dean Askew (research station superintendent at Beef Cattle Center in Butner, North Carolina), Mark Clements and Andy Meier (technician and research station superintendent at Cherry Research Farm in Goldsboro, North Carolina), and Kaleb Rathbone (research station superintendent at Mountain Research Station in Waynesville, North Carolina) for cooperative support at field sites. USDA ARS, USDA Natural Resources Conservation Service (NRCS) Conservation Innovation Grant 69-3A75-14251, North Carolina State University, and North Carolina Department of Agriculture and Consumer Services provided financial support.

\section{References}

Augustine, D.J., D.G. Milchunas, and J.D. Derner. 2013 Spatial redistribution of nitrogen by cattle in semiarid rangeland. Rangeland Ecology and Management 66:56-62.

Bear, A., J.R. Russell, and D.G. Morrical. 2012. Physical characteristics, shade distribution, and tall fescue effects on cow temporal/spatial distribution in Midwestern pastures. Rangeland Ecology and Management 65:401-408.

Brady, N.C., and R.R. Weil. 1999. The nature and properties of soils, 12 Edition. Upper Saddle River, NJ: Prentice Hall.

Bundy, L.G., and J.J. Meisinger. 1994. Nitrogen availability indices. In Methods of Soil Analysis, Part 2, eds. Weaver, R.W., J.S. Angle, and P.S. Bottomley, 951-984. Madison, WI: Soil Science Society of America Book Series 5

Butler, D.M., N.N. Ranells, D.H. Franklin, M.H. Poore, and J.T. Green. 2007. Ground cover impacts on nitrogen export from manured riparian pasture. Journal of Environmental Quality 36:155-162.

Cambardella, C.A., and E.T. Elliott. 1992. Particulate soil organic-matter changes across a grassland cultivation sequence. Soil Science Society of America Journal 56:777-783.

Deiss, L., A.J. Franzluebbers, and A. de Moraes. 2017. Soil texture and organic carbon fractions predicted from

\section{Figure 10}

Extractable potassium $(K)$ concentration at three sampling locations with grazed pastures in the Coastal Plain, Piedmont, and Blue Ridge regions of North Carolina. Low and very high regions are delineated with thin and thick lines, respectively. Increasingly greater size of triangle relates to increasingly greater concentration.
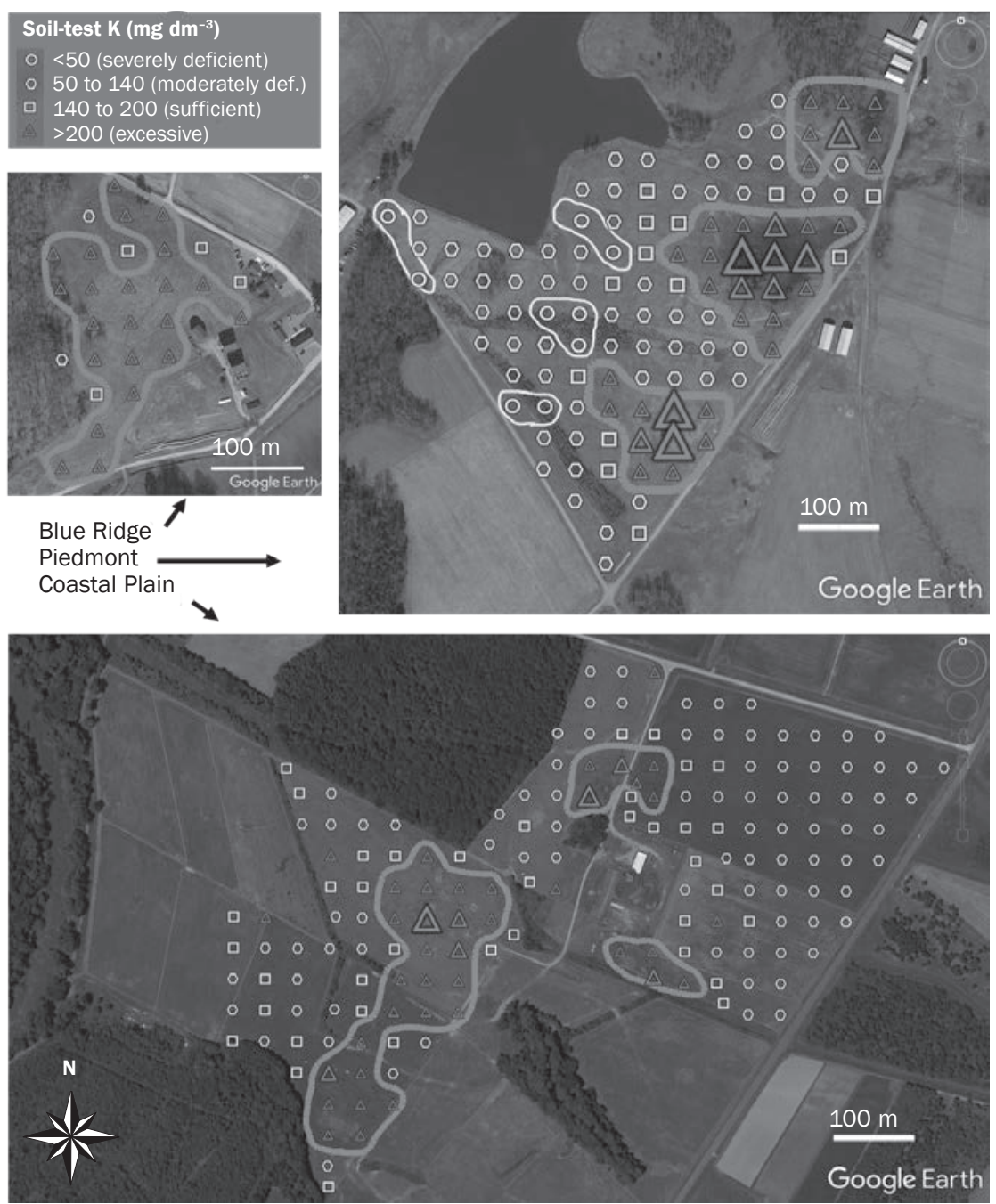

near-infrared spectroscopy and geostatistics. Soil Science Society of America Journal 81:1222-1234.

DeLaune, P.B., P.A. Moore, D.K. Carman, A.N. Sharpley, B.E. Haggard, and T.C. Daniel. 2004. Development of a phosphorus index for pastures fertilized with poultry litter-Factors affecting phosphorus runoff. Journal of Environmental Quality 33:2183-2191

Franzluebbers, A.J. 2016. Should soil testing services measure soil biological activity? Agricultural and Environmental Letters 1:150009.

Franzluebbers, A.J. 2018. Soil-test biological activity with the flush of $\mathrm{CO}_{2}$ : III. Corn yield responses to applied nitrogen. Soil Science Society of America Journal 82:708-721

Franzluebbers, A.J., S. Pehim-Limbu, and M.H. Poore. 2018. Soil-test biological activity with the flush of $\mathrm{CO}_{2}$ : IV. Fall-stockpiled tall fescue yield response to applied nitrogen. Agronomy Journal 110:2033-2049.
Franzluebbers, A.J., and J.A. Stuedemann. 2002. Particulate and non-particulate fractions of soil organic carbon under pastures in the Southern Piedmont USA. Environmental Pollution 116:S53-S62

Franzluebbers, A.J., and J.A. Stuedemann. 2010. Surface soil changes during twelve years of pasture management in the Southern Piedmont USA. Soil Science Society of America Journal 74:2131-2141.

Franzluebbers, A.J., J.A. Stuedemann, and H.H. Schomberg. 2000. Spatial distribution of soil carbon and nitrogen pools under grazed tall fescue. Soil Science Society of America Journal 64:635-639.

Hardy, D.H., M.R. Tucker, and C.E. Stokes. 2014. Crop fertilization based on North Carolina soil tests. Circular No. 1. Raleigh, NC: North Carolina Department of Agriculture and Consumer Services, Agronomic Division. http://www.ncagr.gov/agronomi/obook.htm. 


\section{Table 2}

Correlation matrix among soil properties from 312 samples collected on three research stations in the Coastal Plain, Piedmont, and Blue Ridge regions of North Carolina.

\begin{tabular}{|c|c|c|c|c|c|c|c|c|c|c|c|c|c|c|c|c|c|c|c|c|c|c|c|}
\hline $\begin{array}{l}\text { Soil } \\
\text { property }\end{array}$ & HM & $\begin{array}{l}\text { Den- } \\
\text { sity }\end{array}$ & CEC & BS & $\begin{array}{l}\text { Aci- } \\
\text { dity }\end{array}$ & pH & $\mathbf{P}$ & K & $\mathrm{Ca}$ & Mg & S & $\mathrm{Mn}$ & $\mathrm{Zn}$ & $\mathrm{Cu}$ & $\begin{array}{l}\text { ST- } \\
\text { BA }\end{array}$ & Sand & TSN & TOC & PON & POC & RSN & RSA & RIN \\
\hline $\mathrm{HM}$ & - & 0.05 & 0.09 & $9-0.10$ & 0.33 & -0.15 & 0.10 & 0.02 & 0.11 & -0.03 & 0.09 & 0.05 & 0.05 & -0.08 & 0.04 & -0.03 & 0.11 & 0.15 & -0.01 & 0.04 & 0.06 & 0.12 & 0.11 \\
\hline Density & NS & - & -0.68 & $8-0.45$ & -0.04 & -0.20 & 0.24 & -0.48 & -0.62 & -0.66 & 0.02 & -0.39 & -0.28 & -0.42 & -0.77 & 0.59 & -0.72 & -0.76 & -0.54 & -0.61 & -0.35 & -0.39 & -0.45 \\
\hline CEC & NS & $\star * *$ & - & 0.65 & -0.06 & 0.49 & 0.17 & 0.65 & 0.96 & 0.96 & 0.13 & 0.33 & 0.51 & 0.48 & 0.69 & -0.34 & 0.83 & 0.81 & 0.66 & 0.69 & 0.61 & 0.41 & 0.60 \\
\hline BS & NS & $\star * *$ & $* * *$ & - & -0.69 & 0.86 & -0.08 & 0.40 & 0.74 & 0.68 & -0.17 & 0.15 & 0.27 & 0.32 & 0.45 & -0.25 & 0.42 & 0.39 & 0.27 & 0.27 & 0.29 & 0.28 & 0.35 \\
\hline Acidity & $* * *$ & NS & NS & $* * *$ & - & -0.75 & 0.11 & -0.12 & -0.18 & -0.18 & 0.19 & 0.12 & -0.01 & -0.03 & -0.03 & -0.09 & 0.07 & 0.12 & 0.06 & 0.10 & 0.00 & 0.00 & 0.00 \\
\hline $\mathrm{pH}$ & NS & $\star * *$ & $* * *$ & $* * *$ & $\star * *$ & - & 0.14 & 0.43 & 0.58 & 0.52 & -0.08 & 30.14 & 0.27 & 0.21 & 0.35 & 0.01 & 0.32 & 0.24 & 0.16 & 0.15 & 0.29 & 0.30 & 0.36 \\
\hline$P$ & NS & $\star \star * *$ & NS & NS & NS & NS & - & 0.48 & 0.09 & 0.09 & 0.35 & -0.10 & 0.50 & -0.23 & -0.08 & 0.61 & 0.20 & 0.16 & 0.28 & 0.25 & 0.45 & 0.07 & 0.29 \\
\hline K & NS & $* * *$ & $* * *$ & $* * *$ & NS & $* * *$ & $* * *$ & - & 0.50 & 0.61 & 0.38 & $\begin{array}{ll}3 & 0.18\end{array}$ & 0.58 & 0.20 & 0.53 & 0.00 & 0.70 & 0.67 & 0.62 & 0.65 & 0.64 & 0.38 & 0.60 \\
\hline $\mathrm{Ca}$ & NS & $\star * *$ & $* * *$ & $* * *$ & NS & $* * *$ & NS & $* * *$ & - & 0.89 & 0.04 & 0.33 & 0.44 & 0.49 & 0.65 & -0.36 & 0.76 & 0.72 & 0.55 & 0.57 & 0.53 & 0.40 & 0.55 \\
\hline $\mathrm{Mg}$ & NS & $* * *$ & $* * *$ & $* * *$ & NS & $* * *$ & NS & $* * *$ & $* * *$ & - & 0.08 & 30.26 & 0.46 & 0.47 & 0.63 & -0.33 & 0.75 & 0.73 & 0.65 & 0.66 & 0.55 & 0.32 & 0.51 \\
\hline$S$ & NS & NS & NS & NS & $* * *$ & NS & $* * *$ & $* * *$ & NS & NS & - & 0.05 & 0.22 & 0.12 & 0.08 & 0.00 & 0.27 & 0.24 & 0.30 & 0.28 & 0.38 & 0.23 & 0.36 \\
\hline $\mathrm{Mn}$ & NS & $\star \star *$ & $* * *$ & NS & NS & NS & NS & $* * *$ & $* * *$ & $* * *$ & NS & - & -0.01 & 0.40 & 0.55 & -0.44 & 0.35 & 0.32 & 0.12 & 0.15 & 0.19 & 0.29 & 0.30 \\
\hline $\mathrm{Zn}$ & NS & $* * *$ & $* * *$ & $* * *$ & NS & $* * *$ & $* * *$ & $* * *$ & $* * *$ & $* * *$ & $* * *$ & NS & - & -0.01 & 0.22 & 0.21 & 0.55 & 0.52 & 0.53 & 0.52 & 0.51 & 0.31 & 0.48 \\
\hline $\mathrm{Cu}$ & NS & $\star * *$ & $* * *$ & $* * *$ & NS & $* * *$ & $* * *$ & $* * *$ & $* * *$ & $* * *$ & NS & $* * *$ & NS & - & 0.50 & -0.65 & 0.37 & 0.31 & 0.17 & 0.18 & 0.17 & 0.23 & 0.25 \\
\hline STBA & NS & $\star \star \star *$ & $* * *$ & $* * *$ & NS & $* * *$ & NS & $* * *$ & $* * *$ & $* * *$ & NS & $* * *$ & $* * *$ & $* * *$ & - & -0.53 & 0.78 & 0.76 & 0.52 & 0.59 & 0.39 & 0.53 & 0.57 \\
\hline Sand & NS & $\star \star \star *$ & $\star * *$ & $* * *$ & NS & NS & $* * *$ & NS & $* * *$ & $\star * *$ & NS & $* * *$ & $* * *$ & $* * *$ & $* * *$ & - & -0.28 & -0.29 & -0.03 & $3-0.08$ & 0.08 & -0.16 & -0.07 \\
\hline TSN & NS & $\star * *$ & $* * *$ & $* * *$ & NS & $* * *$ & $* * *$ & $* * *$ & $* * *$ & $* * *$ & $* * *$ & $* * *$ & $* * *$ & $* * *$ & $* * *$ & $* * *$ & - & 0.97 & 0.87 & 0.88 & 0.72 & 0.58 & 0.77 \\
\hline TOC & NS & $\star \star *$ & $* * *$ & $* * *$ & NS & $* * *$ & NS & $* * *$ & $* * *$ & $* * *$ & $* * *$ & $* * *$ & $* * *$ & $* * *$ & $* * *$ & $* * *$ & $* * *$ & - & 0.86 & 0.90 & 0.67 & 0.53 & 0.71 \\
\hline PON & NS & $\star \star \star$ & $* * *$ & $* * *$ & NS & NS & $* \star *$ & $* * *$ & $* * *$ & $* * *$ & $* * *$ & NS & $* * *$ & NS & $* * *$ & NS & $* * *$ & $\star * *$ & - & 0.98 & 0.72 & 0.38 & 0.65 \\
\hline POC & NS & $\star \star * *$ & $* * *$ & $* * *$ & NS & $* * *$ & $* * *$ & $* * *$ & $\star * *$ & $* * *$ & $* * *$ & NS & $* * *$ & NS & $* * *$ & NS & $* * *$ & $\star * *$ & $* * *$ & - & 0.69 & 0.40 & 0.64 \\
\hline $\mathrm{RSN}$ & NS & $\star * *$ & $\star * *$ & $* * *$ & NS & $* * *$ & $* * *$ & $* * *$ & $\star * *$ & $* * *$ & $* * *$ & $* * *$ & $* * *$ & NS & $* * *$ & NS & $* * *$ & $\star * *$ & $* * *$ & $\star * *$ & - & 0.36 & 0.78 \\
\hline $\mathrm{RSA}$ & NS & $\star \star \star$ & $* * *$ & $\star * *$ & NS & $* * *$ & NS & $* * *$ & $* * *$ & $* * *$ & $* * *$ & $* * *$ & $* * *$ & $* * *$ & $* * *$ & NS & $* * *$ & $* * *$ & $* * *$ & $* \star *$ & $* * *$ & - & 0.86 \\
\hline RIN & NS & $\star \star *$ & $\star * *$ & $* * *$ & NS & $* * *$ & $* * *$ & $* * *$ & $\star * *$ & $* * *$ & $* * *$ & $* * *$ & $* * *$ & $* * *$ & $* * *$ & NS & $* * *$ & $\star * *$ & $* * *$ & $\star * *$ & $* * *$ & $\star * \star$ & - \\
\hline
\end{tabular}

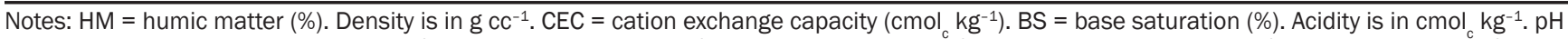
is in $-\log \left[\mathrm{H}^{+}\right] . \mathrm{P}=$ phosphorus $\left(\mathrm{mg} \mathrm{dm}{ }^{-3}\right) . \mathrm{K}=$ potassium $\left(\mathrm{mg} \mathrm{dm}^{-3}\right) . \mathrm{Ca}=$ calcium $\left(\mathrm{mg} \mathrm{dm}^{-3}\right) . \mathrm{Mg}=\mathrm{magnesium}\left(\mathrm{mg} \mathrm{dm}^{-3}\right) . \mathrm{S}=\mathrm{sulfur}\left(\mathrm{mg} \mathrm{dm}^{-3}\right) . \mathrm{Mn}^{-3}$

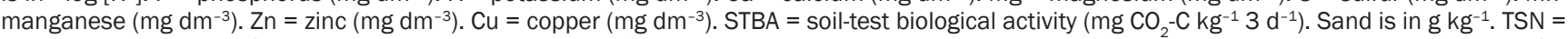
total soil nitrogen $\left(\mathrm{g} \mathrm{kg}^{-1}\right)$. TOC $=$ total organic carbon $\left(\mathrm{g} \mathrm{kg}^{-1}\right)$. PON $=$ particulate organic nitrogen $\left(\mathrm{g} \mathrm{kg} \mathrm{gOC}^{-1}\right)$. POC $=$ particulate organic carbon $\left(\mathrm{g} \mathrm{kg} \mathrm{g}^{-1}\right)$. $\mathrm{RSN}$ $=$ residual soil nitrate $\left(\mathrm{mg} \mathrm{kg}^{-1}\right) . \mathrm{RSA}=$ residual soil ammonium $\left(\mathrm{mg} \mathrm{kg}^{-1}\right)$. RIN = residual inorganic nitrogen $\left(\mathrm{mg} \mathrm{kg}^{-1}\right)$.

$* * *$ Indicates significance at $p \leq 0.001$. NS is not significant.

Karki, U., and M.S. Goodman. 2007. Cattle distribution and behavior in southern-pine silvopasture versus openpasture. Agroforestry Systems 78:159-168.

Klapwyk, J.H., and Q.M. Ketterings. 2006. Soil tests for predicting corn response to nitrogen fertilizer in New York. Agronomy Journal 98:675-681.

Mathews, B.W., L.E. Sollenberger, V.D. Nair, and C.R. Staples. 1994. Impact of grazing management on soil nitrogen, phosphorus, potassium, and sulfur distribution. Journal of Environmental Quality 23:1006-1013.

Merckx, R.,A. den Hartog, and J.A. van Veen. 1985. Turnover of root-derived material and related microbial biomass formation in soils of different texture. Soil Biology and Biochemistry 17:565-569.

NCDA (North Carolina Department of Agriculture and Consumer Services). 2017. Agronomic Services Soil Test Forms and Information. Raleigh, NC: North Carolina Department of Agriculture and Consumer Services. http://www.ncagr.gov/agronomi/uyrst.htm.

Nelson, C.J. (Ed.) 2012. Conservation Outcomes from Pastureland and Hayland Practices: Assessment, Recommendations, and Knowledge Gaps. Lawrence, KS: Allen Press.
Owens, L.B., W.M. Edwards, and R.W. van Keuren. 1997. Runoff and sediment losses resulting from winter feeding on pastures. Journal of Soil and Water Conservation 52(3):194-197.

Owens, L.B., and M.J. Shipitalo. 2009. Runoff quality evaluations of continuous and rotational over-wintering systems for beef cows. Agriculture, Ecosystems and Environment 129:482-490.

Richards, I.R., and K.M. Wolton. 1976. The spatial distribution of excreta under intensive cattle grazing. Journal of the British Grassland Society 31:89-92.

Sanderson, M.A., C. Feldmann, J. Schmidt, A. Herrmann, and F. Taube. 2010. Spatial distribution of livestock concentration areas and soil nutrients in pastures Journal of Soil and Water Conservation 65(3):180-189, doi:10.2489/jswc.65.3.180.

Schomberg, H.H., J.A. Stuedemann, A.J. Franzluebbers, and S.R. Wilkinson. 2000. Spatial distribution of extractable phosphorus, potassium, and magnesium as influenced by fertilizer and tall fescue endophyte status. Agronomy Journal 92:981-986.

Sigua, G.C., and S.W. Coleman. 2006. Sustainable management of nutrients in forage-based pasture soils:
Effect of animal congregation sites. Journal of Soils and Sediments 6:249-253.

USDA NASS (National Agricultural Statistics Service). 2012 Census of Agriculture - Summary and state data,Volume 1, Geographic Area Series, Part 51. Washington, DC: USDA National Agricultural Statistics Service. https:// www.agcensus.usda.gov/Publications/2012/.

West, C.P., A.P. Mallarino, W.F. Wedin, and D.B. Marx. 1989 Soil potassium distribution in grazed K-31 tall fescue pastures as affected by fertilization and endophytic fungus infection level. Agronomy Journal 81:508-512.

Yost, M.A., K.S. Veum, N.R. Kitchen, J.E. Sawyer, J.J. Camberato, P.R. Carter, R.B. Ferguson, F.G. Fernandez, D.W. Franzen, C.A. Laboski, and E.D. Nafziger. 2018. Evaluations of the Haney soil health tool for corn nitrogen recommendations across eight Midwest states. Journal of Soil and Water Conservation 73(5):587-592, doi:10.2489/jswc.73.5.587 